\title{
Phonology and sketch grammar of Kri, a Vietic language of Laos
}

\section{N. J. ENFIELD \& Gérard DIFFLOTH}

This article presents a first sketch of Kri, a Vietic (Austroasiatic) language spoken in upland Laos. This previously undescribed language is of special interest not only in so far as it adds to the typological sample of the world's languages, but also in so far as its complex phonological system adds to our understanding of the historical development of Vietic and Austroasiatic, and more generally to the process of tonogenesis. Kri syllables are defined both in terms of segments and segmental slots, as well as in terms of register ('heavy' versus 'light') and what we call 'terminance' (voiced, voiceless, checked). Register and terminance have this in common with tone that they all involve laryngeal features. The description also contains a sketch of the main morphosyntactic features of the language.

Keywords : Language description, tonogenesis, Austroasiatic, MonKhmer, Vietic, mainland Southeast Asian languages, Laos.

Cet article vient enrichir l'inventaire typologique des langues du monde en décrivant pour la première fois le kri, une langue viétique parlée dans les montagnes du Laos. Son système phonologique complexe contribue aussi à notre compréhension du développement historique des langues viétiques et austroasiatiques, et du processus de tonogénèse en général. Les voyelles du kri se définissent non seulement en termes de segments et de concaténation, mais aussi en termes de registres (lourd ou léger) et de ce que nous appelons 'terminance' (voisée, sourde, ou interrompue). Les oppositions de registre et de terminance ont ceci de commun avec les tons qu'elles font appel à des traits laryngaux. L'article contient aussi une esquisse des principales caractéristiques morphosyntaxiques du kri.

Mots-clés : description linguistique, tonogénèse, austroasiatique, monkhmer, viétique, langues du continent sud-est asiatique, Laos.

Cahiers de Linguistique - Asie Orientale 38(1): 3-69 (2009)

C CRLAO-EHESS 54, Bd Raspail 75006 Paris

0153-3320/2009/038-003 
In this article', we present new facts and analyses from recent field work on a previously undescribed language of mainland Southeast Asia. Kri is an Austroasiatic language of the Vietic branch of Eastern Mon-Khmer. It is spoken by approximately 250 people living in the upper reaches of the Nrong river (or Nam Noy in Lao), a tributary of the Nam Theun, and ultimately the Mekong River, in central Laos. The language has a number of typologically noteworthy features, including derivational infixes, a very crowded vowel system (18 long vowel contrasts), and a complex phonological template which combines segmental structure with cross-cutting rime-level distinctions of register and terminance. In many respects, this language differs from the common vision of a 'typical mainland Southeast Asian language' such as Thai or Vietnamese. Kri is unlike those national languages in several respects, for example its lack of lexical tone, its complex phonological template, its derivational morphology, its possession of unusual sounds such as devoiced rhotic finals and retroflex affricates, and its high number of contrasts in syllable-final position. However, in the context of the types of language which are most numerous yet least described in the area, it is languages like Kri that may be more worthy of the title 'typical' in mainland Southeast Asia.

\footnotetext{
'The data discussed here were collected in four field expeditions carried out by Enfield to Kri-speaking villages of the upper Ñrong valley in 2004-6: first, a brief introductory visit in May 2004; second, five weeks in summer 2004; third, a month in upper Nrong plus a further week with Kri speakers in Nakai District centre, in summer of 2005; and fourth, a month in upper Nrong in summer 2006. Both authors collaborated in analysis of audio-recorded data collected in 2004-2005, and in addition, both authors spent a week working together with Kri speakers in Nakai, upland central Laos, in August 2006. We gratefully acknowledge the input of audiences at Siem Reap (2006), Nijmegen (2007), and Leipzig (2007), and helpful comments from those who read drafts, including Frans Plank and Larry Hyman, as well as a number of anonymous reviewers. Errors of fact or interpretation remain our responsibility. We thank the Max Planck Society and especially Steve Levinson for support of this work.
} 
Phonology and sketch grammar of Kri, a Vietic language of Laas / CLAO 38(2009) 3-69

In terms of morphological type, Kri tends toward an isolating and analytic profile (no inflectional morphology such as casemarking or verb-argument agreement). It has a modest inventory of essentially non-productive derivational morphology, including infixation (causative, verbalizing, and nominalizing) and reduplication. The phonological system features a large number of vowel distinctions, and has other properties of significant interest for research on the history of Vietic and other Austroasiatic languages. These include the retention of syllable-level contrasts in register (heavy versus light) and terminance (checked versus voiced versus voiceless) which are understood to set the stage for the kind of tonogenesis hypothesized for Vietic languages such as Vietnamese and Muong, as well as other languages of Southeast Asia such as Kmhmu and Chinese. In this sense, Kri may be regarded as conservative, retaining features that have long since changed in better-known languages of the same branch.

In the current state of knowledge of this language, the best worked-out component of the grammar is the phonology. We therefore concentrate in this article on the sound system in some detail before sketching certain of the morphosyntactic features. But first, some information about the context of the language.

\section{KRI SPEAKERS AND THEIR SETTING}

Kri is spoken in the upper valley of the Nrong river, in Khammouan Province, Laos. The area lies about $300 \mathrm{~km}$ due East of the capital city, Vientiane, about $90 \mathrm{~km}$ Northeast of the Lao city of Thakhek on the Mekong River, and about $60 \mathrm{~km}$ Southwest of the Vietnamese coastal city of Ha Tinh on the South China Sea. The villages lie between $600 \mathrm{~m}$ and $700 \mathrm{~m}$ above sea level, just on the Western side of the Annamite Chain ridge. The Nrong valley lies in the path of shortest distance anywhere in Laos from the Mekong to the South China Sea. For this reason, the area has long been a trade 
route, as documented in Vietnamese administrative archives since the early 17th century (Quy 2002).

Kri territory is situated deep inside the area of highest biodiversity in all of Laos. The Northern Annamites Rain Forests area is one of the Global 200 ecoregions that are 'outstanding examples of biodiversity' in the world (ADB/UNEP 2004:72). It is also a site of significant ethnolinguistic diversity. Three main ethnolinguistic groups in the area are Katuic (Austroasiatic) (e.g., speakers of Bru), Tai (Austroasiatic) (e.g., speakers of Tai Mène and Sek, also known as Saek), and Vietic (speakers of a range of highly endangered Vietic languages such as Thémarou and Ahlao; see Ferlus 1996 on the languages and peoples of the Vietic group more generally).

As Chamberlain (1997) describes it, the Vietic speakers are the earliest of the current inhabitants, with speakers of Northern Tai languages such as Sek arriving some 300 years ago, and Bru speakers arriving (from lower areas along the Korat Plateau in present-day Thailand) over the course of the last century or so. Tai speakers came in search of flat irrigable land on which to grow wet rice crops. The group most closely related to the Kri are the Phòngq, who live in several villages further downstream on the Ñrong. The Kri and Phòongq languages are mutually intelligible - that is, they may be regarded as dialects of a single language. The two varieties differ in their phonological systems, with Phòngq showing a clear development of lexical pitch contrast, as well as showing differences from Kri in lexicon. Kri speakers also come into regular contact (as has likely been the case for some hundreds of years) with speakers of Vietnamese (mostly itinerant hiker-traders), and speakers of Lao, including local dialects spoken around the lowland villages far downriver from the Kri, as well as the modern national language spoken in the extreme lowlands, along the Mekong River (Enfield 1999, 2007).

The word $K r i$ is an autonym (as in mleeng $K r i$ 'Kri people', meengq $\mathrm{Kri}$ 'Kri language', or bruuq $\mathrm{Kri}$ ' $\mathrm{Kri}$ forest/territory'). The word also refers to other Vietic groups of the area. The Lao word 
khaa is widely considered to be pejorative with its reference to upland minority people (the word also means 'slave'). Rivière's (1902) term for the Kri is Harème, clearly from the word Arem used by Bru speakers to refer to the Kri. ${ }^{2}$ Another word which has been used for the Kri is Salang or Salaang. Its origin is unknown, and its reference is uncertain (as it has been used with reference to other groups as well). The word $\mathrm{Kri}$ is otherwise a verb meaning 'to growl' (karii), with a cognate of similar meaning in neighboring Bru.

Kri tradition is to periodically move around, within a delineated 'home range' territory in the upper reaches of the Ñrong, practicing shifting cultivation, mostly on flat land alongside riverbanks. Relocation is frequent. A house will be abandoned by its builder/owner within about five years from construction, for example due to death in the family. Traditionally, upon death of a family member (small children are an exception), the house is dismantled and rebuilt on another location, anywhere from a few meters away to several kilometers away in another village location. The floor of the house is always discarded after a death in the household. (See Enfield 2009 for an ethnographic description of the Kri house.)

Material culture is not elaborate. There is little in the way of decorative art, no weaving of cloth or other production of clothing, no decorative carving apart from very simple fashioning of window frames, for example. Unlike many Bahnaric and Katuic speaking groups further South, there is no special decoration of the house. The main tool is a well-sharpened machete. Basketry is the one relatively elaborated area of material culture. The techniques used are widespread across mainland Southeast Asia. An initial phase of preparing weave-strips (laac) precedes the hand weaving of a large range of practical artifacts, including baskets of many shapes and sizes, and several types of fish trap (although of limited range compared to the repertoire of the lowland Lao). Basketry is men's work.

\footnotetext{
${ }^{2}$ Ethnologue.com has no entry for Kri, but it may correspond to the language listed as Arem (although the information supplied differs in some ways from that given here).
} 
Kri adults are multilingual, speaking Kri, Vietnamese, Sek, Bru, and Lao. The men have some advantage over the women in this respect, since they travel more widely and more often. The men go to market semi-regularly, and many of them spend a period in the army, traveling to other provinces of Laos. Kri villagers have extensive contact with other ethnolinguistic groups, most proximally Sek and Vietnamese, but also including other Vietic groups, especially the Phòongq who live a short way downstream.

Descent is patrilineal, as reckoned through house spirits. In practice, a family is typically first established under the bride's house spirits, the young couple later moving to the groom's father's house when he can afford the bride price (which includes 2 pigs, one very big and one very small). Kinship is utterly central to the organization of life and of people's relationship practices, particularly as manifest in linguistic practice. Religion is animist with spirits often being consulted. As is typical in this area, animist beliefs and practices are sometimes combined with aspects of statesponsored religion, in this case Buddhism (with a small number of Kri men having spent time in the monkhood). Women are required to 'remain on the ground' during menstruation - that is, they are not to go up into their houses. Instead, they sleep in small raised huts built for this purpose. The Kri have traditionally upheld widespread restrictions on what kinds of food may be eaten, a very unusual trait for people of this area: they avoid eating domesticated red meat, large animals of any kind, and many kinds of smaller non-plant food sources such as snakes, insects and birds. However, this, like many traditional aspects of Kri life, is rapidly changing.

\section{SOUND SYSTEM OF KRI}

This section outlines the basics of Kri phonology. By way of a preview, first note the following basic features of the Kri sound system, to be elaborated upon in following sections: 
- Word structure: Any Kri word has one stressed syllable. If a word has two syllables, the first will be unstressed, and will be phonotactically constrained in other ways as well.

- Vowels: The vowel system features a large number of contrasts: 18 long vowels, 12 short vowels, and 3 diphthongs.

- Register: The high number of vowels is brought about by a thoroughgoing contrast in the phonological system at each of nine points in the vowel space, between two registers: 'heavy' (tending to be breathy in voice quality, with somewhat raised vowel height) and 'light' (tending to be tight in voice quality, with somewhat lowered vowel height).

- Initial vs. final consonants: In the inventory of consonants, there are many more initials than finals. Initial stops show a three-way contrast in voice onset time, including a series of voiced implosives. Word-final stops show no contrast in voicing.

- Terminance: In word-final position, there is a systematic contrast between three types of terminance (see section 2.2, below, for explication of this term) - voiced, voiceless, and checked. ('Checked' is used here to mean 'with full obstruction of airflow and without immediate release'.) The full three-way contrast is realized for oral sonorant finals $\left(e . g .[-1]\right.$ vs. $\left[-1^{3}\right]$ vs. $[-1])$, whereas only a two-way distinction is realized for nasal finals (voiced versus checked, e.g., [-n] vs. $\left[-\mathrm{n}^{2}\right]$ ), and final stops show no contrast, being always checked (e.g., $\left.\left[t^{7}\right]\right)$.

- Register and terminance cross-cut, yielding.six possible syllable types, structurally and historically comparable to tones: heavy checked, heavy voiced, heavy voiceless, light checked, light voiced, light voiceless. Such a division of syllable types is understood to have set the stage for tonogenesis in Vietic languages such as Vietnamese and Muong (cf. comparable processes in other tone languages of mainland Southeast Asia; cf. Haudricourt 1954, Norman 1988, Thurgood 2002). 


\subsection{Consonants}

As many have done in research on sounds systems of Southeast Asian languages, we treat initial and final consonants as belonging to distinct systems. ${ }^{3}$ First, it is useful to note the basic segmental structure of the Kri word: ${ }^{4}$

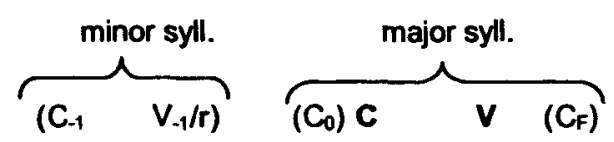

Figure 1. Segmental structure of the Kri word (non-segmental features not specified here; see Figure 2, below, for full details, including terminance and register).

Within this structure, $\mathrm{C}$ is defined as the segmental onset of the stressed or major syllable. C may or may not be initial to the word, depending on whether the major syllable is preceded by a minor (unstressed) syllable. The term we use for $C$ is major initial consonant. This does not mean that $C$ is necessarily wORD-initial, although it may be. The term we use for $C_{F}$ in Figure 1 is final consonant. The term we use for $\mathrm{C}_{-1}$ in Figure 1 is minor initial consonant. When $\mathrm{C}_{0}$ is realized, the major syllable onset is a CC cluster. ${ }^{5}$ Where necessary, we use the term Pre-C consonant to refer to any consonant which comes before $\mathrm{C}$ (i.e., either $\mathrm{C}_{0}$ or $\mathrm{C}_{-1}$ ). We use the term rime to refer to the stressed vocalic element along with

\footnotetext{
${ }^{3}$ Following work on other Southeast Asian languages, we regand a distinction between onset and rime as the main distinction in the Kri syllable. Sino-Tibetan, Tai, and Hmong-Mien linguistics have all done this traditionally.

${ }^{4}$ Words with more than two syllables occur, but are very rare. An example is the word for one's great-great-grandchild: celcvec. As in other Kri words, the final syllable receives full stress.

${ }^{5}$ These are not always true clusters in phonetic terms, due to the insertion of a predictable epenthetic vowel in many CC sequences (e.g., /kt-/ [ $\left.\mathbf{k}^{*} t-\right] \mathrm{CC}$ - vs. /kat/ [kat-] CvC-). See section on phonotactics, below.
} 
the following consonant (i.e., the word final consonant) if there is one. We use the term onset to refer to the material which precedes the rime.

\subsubsection{Major initial consonants}

Table 1 lists the full inventory of major initial consonants:

labial alveolar retroflex palatal velar laryngeal

\begin{tabular}{|c|c|c|c|c|c|c|}
\hline \multicolumn{7}{|l|}{ stops } \\
\hline voiced (implosive) & 6 & $\boldsymbol{d}$ & & $f$ & & \\
\hline voiceless aspirated & $\mathbf{p}^{\mathbf{h}}$ & $\mathbf{t}^{\mathbf{h}}$ & tw & & $\mathbf{k}^{\mathbf{h}}$ & \\
\hline voiceless unaspirated & $\mathbf{p}$ & $t$ & $t$ & c & $\mathbf{k}$ & $?$ \\
\hline fricatives & & $\mathbf{s}$ & & & $\mathbf{Y}$ & $\mathbf{h}$ \\
\hline nasal sonorants & $\mathbf{m}$ & $\mathbf{n}$ & & $\mathbf{n}$ & n & \\
\hline oral sonorants & $\mathbf{v}$ & $1 \mathrm{r} / \mathrm{z}_{\mathrm{L}}^{\mathrm{J}}$ & & $\mathrm{j} / \mathbf{j}$ & & \\
\hline
\end{tabular}

Table 1. The 24 major initial consonants. ${ }^{6}$

We now supply some illustrative lexical contrasts. ${ }^{7}$

(1) Bilabial initial stops with different manners of articulation $\begin{array}{lll}\text { Impl. } & \text { V'less } & \text { Asp'd } \\ \text { 69: 'flank' } & \text { pq: 'three' } & \mathbf{p}^{\mathbf{h}} \text { : 'to cool' }\end{array}$

${ }^{6}$ Note: $x / z^{2}$ and $j / /$ represent freely varying allophones.

${ }^{7}$ Throughout this article, for convenience of presentation, we give simplified glosses of the meaning of example words. Often, the lexical meanings are more specific than we supply here. The authors may be contacted for more information. 
12

Enfield N.J. \& Diffloth G. / Cahiers de Linguistique - Asie Orientale 38(2009) 3-69

(2) Alveolar initial stops with different manners of articulation Impl. V'less Asp'd dgm 'five' toj 'French' thej 'to change'

(3) Retroflex initial stops with different manners of articulation V'less Asp'd

tog: 'a swidden' tom 'a rack'

Note also that the retroflex initials contrast with phonetically similar clusters:

(4) Retroflex initial stops and phonetically similar clusters

$\begin{array}{lllll}\text { V'less } & \text { Asp'd } & \text { tr- } & \text { tar- } & \text { trh- } \\ \text { t'gn } & \text { togj } & \text { trak' } & \text { targak' } & \text { trhitt' } \\ \text { 'bird sp.' } & \text { 'upset' } & \text { 'lead' } & \text { 'wake' } & \text { 'to suck' }\end{array}$

(5) Palatal initials with different manners of articulation

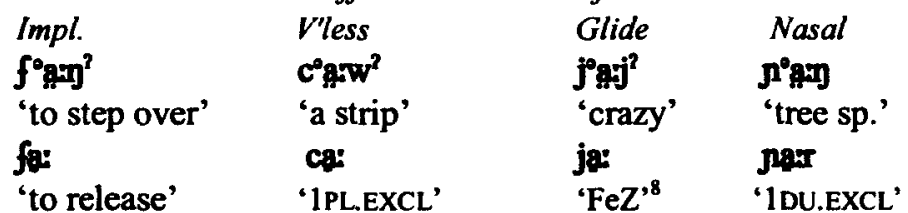

(6) Velar initial stops with different manners of articulation

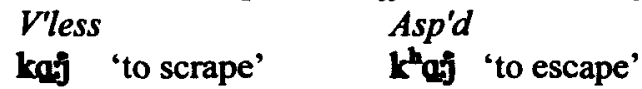

(7) Laryngeal initial stops with different manners of articulation

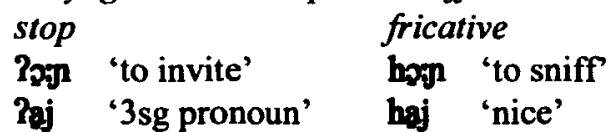

${ }^{8}$ See footnote 19. 
Phonology and sketch grammar of Kri, a Vietic language of Laos / CLAO 38(2009) 3-69

(8) Rhotic initials

l-

lorc' 'oversized' z'orc' 'belly, guts'

As Table 1 shows, the system of major initial consonants is not perfectly symmetrical. There are gaps. In the stops, we do not see full symmetry in distinctions in voicing for all places of articulation. First, there is no voiced stop in velar position to complement $k$ and $k^{h}$. A voiced velar stop is occasionally found in the phonology of related languages (e.g. Katu; Costello 1993:vii), but these contrasts have disappeared in much of the mainland South East Asia area, probably due to a historical process of devoicing (Haudricourt 1946). Languages like Bru, Thai, Lao, and Khmer do not have voiced velar stops in their phonological systems. These languages only have voiced initials in positions further forward, showing an analogous gap.

Implosive articulation of the voiced stops, while typologically unusual across languages of the world, is not unusual for an Eastern Mon-Khmer (EMK) language (though it does not tend to occur today in other language families of mainland Southeast Asia). It represents the proto-EMK state of affairs. Where EMK languages have implosive stops, these tend to be an historically recent development, and are often even fewer in number, normally only including $\mathbf{6}$ and $\boldsymbol{d}$, as in some modern varieties of Khmer. If a language has more than 6 and $d$ in an implosive series, the next addition will be palatal $f$, as found in Kri. It is more rare to find an implosive in velar position $\mathbf{g}$ - this occurs, for example, in Nya Hoen (e.g., gjk 'to cough'; Diffloth field notes; $c f$. Sidwell and Jacq 2003:137, and Davis 1968, cited therein). In Vietnamese, there is a phonological category of voiced velar stop (Thompson 1987:28), but it is phonetically not a stop, rather it is (in most contexts at least) a fricative $\mathbf{Y}$.

The retroflex stops are affricated, and are anomalous in not having voiced, nasal, or oral sonorant counterparts, and in not 
having any counterparts in final position. It is not possible to regard these as, say, clusters of $t$ and $r$, since there is a clear contrast between [tr-] and [ $t-$ ] (which both contrast, in addition, with [tar-]; cf. [traik'] 'lead (a type of metal)' vs. [t'a:n] 'a rack' vs. [tarak'] 'to wake in fright'). Additionally, only the unaspirated retroflex initial occurs in minor initial position, and in that position it is not contrastive. It occurs there in free variation with [r-] (e.g., the word which means 'new' may be pronounced variously as [r'moi], [द language to have retroflexes (but $c f$. some varieties of Vietnamese for a retroflex initial in words like trên 'above', and Beijing Mandarin for retroflex fricatives in words like shi $\left[\mathbf{s}^{24}\right]$ ' $t$ ten').

There is a fricative/continuant $Y$ at the velar place of articulation. This segment occurs in two other languages in close contact with Kri: Vietnamese and Sek (Thompson 1987, Gedney 1993:xxv). However, it is marginal in Kri. The only clear case we have is the borrowing [Ye?] 'scabies' (cf. Vietnamese ghe). There is no historical background for such a velar fricative segment in Austroasiatic (i.e., there is no reconstruction of a velar fricative at any early stage of Austroasiatic, see Diffloth (1984), Sidwell (2005), Shorto (2006)).

Aspirated stops play a minor role in the system. The lexical type frequency ${ }^{9}$ of aspirated stops is very much lower (less than one to seven overall) than the unaspirated counterparts. In a list of 2778 lexical items, we have: ${ }^{10}$

\footnotetext{
${ }^{9}$ By lexical type frequency of a phonological element, we mean its frequency of occurrence across entries in the lexicon, independent of its discourse token frequency, i.e., how often it occurs in discourse. (The distinction can make a world of difference - witness English / $/$ /, with low lexical type frequency, but very high discourse token frequency, thanks to the extremely common occurrence of a small set of words including the, this, that, there, then.)

${ }^{10}$ We do not list the retroflex initials here, since they do not pattern as a set with the other initial stops - the two retroflex initials have very low type frequency, occurring only about 10 times each in our lexicon of 2778 words.
} 
Phonology and sketch grammar of Kri, a Vietic language of Laas / CLAO 38(2009) 3-69

(9) Lexical type frequency of unaspirated versus aspirated stop initials p vs. $\mathbf{p}^{\mathrm{h}}=\quad(208 \mathrm{vs.} 26$ from 2778 words in lexicon) t vs. $\mathrm{t}^{\mathrm{h}}=$ (229 vs. 35 from 2778 words in lexicon) $k$ vs. $k^{k}=(246$ vs. 43 from 2778 words in lexicon $)$

Furthermore, most words with aspirated stops are borrowings (Sek, Vietnamese, or Lao):

(10) Borrowings with aspiration

(a) $\mathrm{p}^{\text {h }} \mathrm{gnn}^{\text {2 }}$ 'to dance' (Lao foòn4)

(b) thop' 'a meal' (Sek thraap5 'a meal')

(c) the ch' 'to measure' (Lao thèek4 'to measure')

(d) k $\mathbf{k}^{\mathrm{h}} \mathrm{gk}$ ' 'great' (Lao khakl 'great')

There is no aspirated palatal [ $\left.\mathbf{c}^{\mathrm{h}}\right]$ to complete a series with $\left[\mathbf{p}^{\mathbf{h}}, \mathbf{t}^{\mathbf{b}}, \mathbf{t}^{\text {sh }}\right.$, $\mathbf{k}^{\mathbf{h}}$ ], by analogy with [p, t, $\left.\mathbf{t}^{\mathbf{t}}, \mathbf{c}, \mathbf{k}\right]$. This gap is also attested in both Lao and Vietnamese, two major contact languages for Kri speakers. However, some languages elsewhere in the area do feature an aspirated palatal stop (e.g. Thai and Khmer).

\subsubsection{Final consonants}

In mainland Southeast Asian languages, initial consonants and final consonants typically belong to distinct systems. The finals always form a smaller set, showing absence or neutralization of contrasts which are found in initial position. Extreme cases can be observed in languages of the Hmong-Mien family (see Ramsey 1987:282 on Miao). A more typical example is Standard Thai. In Standard Thai, initial stops show a three-way contrast in voice onset time (e.g., $/ \mathbf{b}-/, / \mathbf{p}-/, / \mathbf{p}^{\mathbf{k}}-\varsigma$ ), while final stops have a single value, namely checked or unreleased (e.g., /-p $7 /$; this is voiceless, but there is no contrasting voiced stop in final position). The same thing is true for stops in Kri, as shown above (Table 1 and following examples). In this sense, Kri is typical. However, going beyond the stops, the Kri system shows an unusually high number of contrasts 
in final position for a mainland Southeast Asian language. The number of contrastive oppositions in manner for sonorant finals is greater than that for initials. The system furnishes systematic contrasts between voiced, post-glottalized, and devoiced finals.

Table 2 lists the full inventory of final consonants, over which distinctions in terminance are laid:

\begin{tabular}{|c|c|c|c|c|c|}
\hline & & bilabial & alveolar & palatal & (post) velar \\
\hline stops & & $\mathbf{p}^{\top}$ & $\mathbf{t}^{\mathbf{\top}}$ & $c^{\prime}$ & $\mathbf{k}^{\mathbf{3}}$ \\
\hline \multirow{2}{*}{ sonorants } & \multirow{2}{*}{ nasal } & m & $\mathbf{n}$ & $\mathbf{n}$ & D \\
\hline & & $\mathbf{w}$ & $1 \quad \mathrm{r}$ & $\mathbf{j}$ & $\mathbf{v}$ \\
\hline
\end{tabular}

Table 2. Final segments (13), phonologically $(V=$ vowel).

The following examples illustrate these finals realized with contrasts in terminance (a three-way distinction for the final oral sonorants, and a two-way distinction for the final nasal sonorants):
(11) (a) to:j 'tail'
(b) ża: 'turtle'
t'aja' 'bowl'
tọg 'follow'
(c) camgal 'shiny'
z'a:? 'pig basket' z'q 'dry'
(d) kause 'stir'
?umgl? 'to hunt'
dil 'to bounce'
buvigrar' 'embrace'
'to run out of
(e) caresw 'green'
sargew $w^{2}$ to raise/ workspace'
(f) jogm 'sugar cane'
feed'
blowy 'four-eyed
(g) kan 'oversize'
jegm? 'to cry'
(h) 6yp 'dust'
(i) cog 'tree sp.'
kann 'to hunt by night'
purn' 'tree sp. (licuala sp.)'
$\mathbf{c o m}^{2}$ 'salty' 
We do not analyze these syllable-final contrasts as involving extra segmental material (e.g., in an extended set of final consonants, or in a second final consonant slot in the phonotactic template). Instead, we treat the distinctions in (11) as being the product of non-segmental, rime-level features.

We now establish that the final segments listed in Table 2 are lexically contrastive:

(12) Stop finals with different places of articulation
$L a b$
Alv
Pal
Velar

kgap' 'to wash' Gott' 'to rub' Goec' 'mushroom' Gokk' 'to scoop'

(13) Nasal finals with different places of articulation
$L a b$
Alv $\quad P a l$
Velar
dorm 'to perch'
don 'bent' logn 'sharp' tom 'to tap'

(14) Oral sonorant finals with different places of articulation
$L a b$
Alv
Lat
Pal
saww 'ascend'
hgrr 'two'
masgil 'tuber sp.'
saj 'ear'

(15) Bilabial finals with different manners of articulation

$\begin{array}{lll}\text { Stop } & \text { Nasal } & \text { Glide } \\ \text { katap' 'basket type' } & \text { katam 'crab' } & \text { kaw 'turtle sp.' }\end{array}$

(16) Alveolar finals with different manners of articulation

$\begin{array}{llll}\text { Stop } & \text { Nasal } & \text { Lateral } & \text { Rhotic } \\ \text { kat' 'to bite' kgan 'oversize' } & \text { zipgal 'butt, end' } & \text { har 'two' }\end{array}$

(17) Palatal finals with different manners of articulation

\begin{tabular}{|c|c|c|c|}
\hline $\begin{array}{l}\text { Stop } \\
\text { 6quc' } \\
\text { 'mushroom' }\end{array}$ & $\begin{array}{l}\text { Nasal } \\
\text { Gym } \\
\text { 'dust' }\end{array}$ & $\begin{array}{l}\text { Glide } \\
\text { 6xjj } \\
\text { 'scold' }\end{array}$ & $\begin{array}{l}\text { Post-glottalized } \\
\text { 6orj" } \\
\text { 'salt' }\end{array}$ \\
\hline
\end{tabular}


Enfield N.J. \& Difloth G. / Cahiers de Linguistique - Asie Orientale 38(2009) 3.69

Note with regard to the palatal finals that there is a contrast between the phonetically similar checked palatal stop final $-c^{\top}$ and postglottalized palatal glide $-\mathrm{j}$ ?:

(18) Stop

Gare' 'mushroom'

ha:c' 'slippery'

Pace' 'go'
Post-glottalized

6ojj' 'salt'

haj'? 'to strip'

kgoj" 'head hair'

(19) Velar finals with different manners of articulation

Stop

Nasal

dgak' 'water' (Mon 'tree sp. (Murraya paniculata)'

Comparing Tables 1 and 2, we see that the systems of initial and final consonants are strikingly non-equivalent. Looking first at the stops, there are thirteen distinct units in initial position (Table 1) versus four in final position (Table 2). In final position, stops are

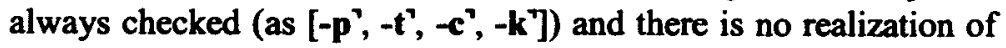
lexical contrast in aspiration, voicing, or implosive articulation." Accordingly, none of the gaps in the initial stop series (e.g. implosive velar stop, aspirated palatal stop) are evidenced in final position. That is, there are no contrasts in manner of articulation for final stops. However, beyond the stops, we do find contrasts in manner of articulation. This arises through a rime-level phenomenon which we refer to as syllable terminance, to which we now turn.

\subsection{Syllable terminance}

Every rime (and therefore every major syllable - see phonotactics below) must have a terminance value, where there are

\footnotetext{
"In utterance-final position, final stops are often pronounced with a kind of delayed voiceless aspiration (e.g., [siit' $t^{\text {'] }}$ ] as a variant of [siit'] for 'animal'). This is not lexically contrastive, but is some kind of stylistic practice whose meaning is not yet clear.
} 
Phonology and sketch grammar of Kri, a Vietic language of Laas / CLAO 38(2009) 3-69

three possibilities: voiceless, voiced, and checked. (Note that by 'checked' we mean 'with full obstruction of airflow and without immediate release', thereby generalizing across cases involving final stops - which already show full obstruction of airflow and lack of immediate release in final position - and those involving final sonorants, which require post-glottalization in order to bring about full obstruction of airflow.) Not all classes of final consonant show all terminance values:

(20) Distribution of terminance distinctions across the three classes of final segment

\begin{tabular}{|c|c|c|c|}
\hline Realized with & $\begin{array}{l}\text { Final } \\
\text { stops }\end{array}$ & $\begin{array}{l}\text { Final } \\
\text { nasals }\end{array}$ & $\begin{array}{c}\text { Final oral } \\
\text { sonorants }\end{array}$ \\
\hline Checked Terminance & $\checkmark$ & $\checkmark$ & $\checkmark$ \\
\hline Voiced Terminance & 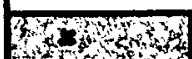 & $\checkmark$ & $\checkmark$ \\
\hline Voiceless Terminance & 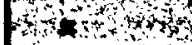 & 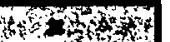 & $\checkmark$ \\
\hline
\end{tabular}

Voiceless terminance. Oral sonorant finals $/-\mathbf{V},-\mathbf{j},-\mathbf{r},-\mathbf{l},-\mathbf{w} /$ may occur with voiceless terminance, where offset of the final element is devoiced, as $[-Y,-j,-[,-1,-w]$. This contrasts with voiced terminance $[-V,-j,-r,-1,-w]$ and checked terminance $\left[-V^{2},-j^{2},-r^{2},-I^{2},-w^{2}\right]$.

Since terminance distinctions of this kind are relatively rare in mainland Southeast Asia (though phonemically contrastive postglottalization does occur in some other languages, e.g., some Tibeto-Burman languages of the Kuki-Chin-Naga branch), we want to provide as extensive evidence as we can to characterize these contrasts. First, it is important to note asymmetries in frequency in our set of 2778 lexical entries: 


\begin{tabular}{lllll}
\hline $\begin{array}{c}\text { Final } \\
\text { segment }\end{array}$ & $\begin{array}{c}\text { Total type } \\
\text { occurrences }\end{array}$ & $\begin{array}{c}\text { w/ Voiced } \\
\text { terminance }\end{array}$ & $\begin{array}{c}\text { w/ Checked } \\
\text { terminance }\end{array}$ & $\begin{array}{c}\text { w/ Voiceless } \\
\text { terminance }\end{array}$ \\
\hline$-\mathrm{V}$ & 616 & $253(41 \%)$ & $184(30 \%)$ & $179(29 \%)$ \\
$-\mathrm{j}$ & 202 & $102(50 \%)$ & $63(31 \%)$ & $37(19 \%)$ \\
$-\mathrm{r}$ & 189 & $98(52 \%)$ & $66(35 \%)$ & $25(13 \%)$ \\
$-\mathrm{I}$ & 135 & $74(55 \%)$ & $58(43 \%)$ & $3(2 \%)$ \\
$-\mathrm{w}$ & 94 & $55(59 \%)$ & $38(40 \%)$ & $1(1 \%)$ \\
\hline
\end{tabular}

Table 3. Type frequencies of final oral sonorants and their occurrence with different terminance distinctions (as absolute number and as percentage of all type occurrences of that final segment with the relevant terminance value).

We now list examples which establish the relevant contrasts, beginning with the lowest frequency case, $-w$, for which we have a single example to date of voiceless terminance:

(21) Terminance distinctions in $-w$

$\begin{array}{lll}\text { Voiced } & \text { Voiceless } & \text { Checked } \\ \text { carew } & 6 l e w y & \text { sareww' } \\ \text { 'green' } & \text { 'four-eyed turtle' } & \text { 'to raise; to feed' }\end{array}$

(22) Terminance distinctions in -l

\begin{tabular}{|c|c|c|}
\hline $\begin{array}{l}\text { Voiced } \\
\text { dql 'to shut off' } \\
\text { kol 'fish sp.' } \\
\text { togl 'to cook in tube' }\end{array}$ & 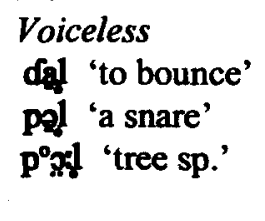 & 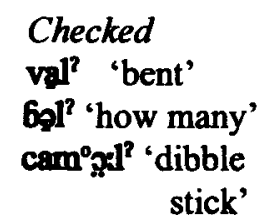 \\
\hline
\end{tabular}

(23) Terminance distinctions in $-V$
Voiced
Voiceless
z'o: 'turtle'
kgi 'chicken'
ziq: 'to be dry'
ka: 'all'
Checked
ky: 'a shoot'
tuky: 'leaf'
द
Paka? 'fish'
caky: 'a bear' 
Phonology and sketch grammar of Kri, a Vietic language of Laos / CLAO 38(2009) 3-69

(24) Terminance distinctions in $-r$

\begin{tabular}{|c|c|c|}
\hline $\begin{array}{l}\text { Voiced } \\
\text { cir 'strips' } \\
\text { kinger 'spur' } \\
\text { suesr 'chipped' } \\
\text { kumjir 'ant sp.' } \\
\text { pcogr 'slat' }\end{array}$ & $\begin{array}{l}\text { Voiceless } \\
\text { jirg 'to shake' } \\
\text { leqt 'root' } \\
\text { vert 'to separate' } \\
\text { Pining 'tree sp.' } \\
\text { j"gr 'far' }\end{array}$ & 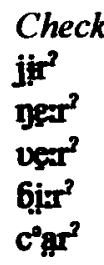 \\
\hline
\end{tabular}

(25) Terminance distinctions in $-j$

tavaj 'happy' faugi 'tuber sp.' rugij' 'a spirit'

lяj 'patterned' calgy 'sit at fire' loji 'to succeed'

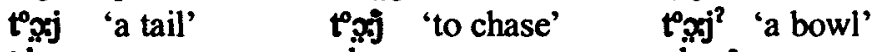

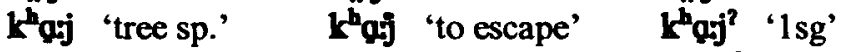

kutpj 'dog's vagina' kutxj 'tuber sp.' krtaje? 'bird sp.'

proxj 'forget' turnje 'boiling' ryj' 'fall off'

Note that the devoiced final oral sonorants $-\boldsymbol{r}$ and $\mathbf{j} \mathbf{j}$ are almost in complementary distribution, with $-\mathbf{r}$ occurring after front vowels, and $-j$ occurring after back vowels. The explanation is historical, with devoiced $-r$ and $-j$ corresponding to a word final *-s (now absent in Kri). Words with final $-r$ and $-j$ correspond to words with final $-s$ in related languages: for $-r$ versus $-r$, compare cognates Kri leyt 'root' and Tariang rias 'root' (Theraphan 2001:485) versus Kri sapigr 'pumpkin' and Nyah Kur cmpiir 'pumpkin' (Diffloth 1982:92); for $-\mathrm{j}$ versus $-\mathrm{j}$, compare cognates Kri moj 'gnat' and Stieng moxs 'mosquito' (Haupers 1979) versus Kri tmojj 'guest' and Kmhmu tmbsj 'stranger' (Svantesson et al 1994:215).

The idea that devoiced $-r$ and $-j$ correspond to a word final *-s is further supported by type frequency: TAKEN TOGETHER, $-r$ and $-j$ show a similar frequency to other SINGLE palatal finals $(e . g .,-c$ or $-\pi)$. If we identify devoiced vowel finals $-V$ with erstwhile $/ h /$ in final consonant position, a possible scenario is that after a development of $-s$ into $-r$ and $-j$ in complementary environments, these became 
aligned with $-\boldsymbol{Y}$ in a paradigmatic series of devoiced terminant sonorants. Subsequent innovation of parallel devoiced versions of $-w$ and $-I(-y$ and $-I)$, might have then filled the gaps, bringing all oral sonorants into line as a set (through Sapir's 'drift', to avoid the 'psychological shakiness' of having empty cells in the system; Sapir 1921:154-8).

In synchronic terms, however, the devoiced final oral sonorants $-r$ and $-j$ are distinct entities. The following examples show that they contrast after $-\mathrm{a}-$ :

(26)

$$
\begin{aligned}
& \text { Contrast between }-r \text { and }-j \\
& -f \\
& \text { tar 'to reach the end' } \\
& \text { jogr 'far' } \\
& \text { Pugr 'to jiggle' } \\
& \text { mor 'to speed up' }
\end{aligned}
$$

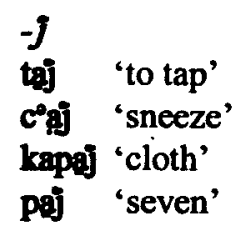

We do not know how the contrast between final $-r$ and $-j$ after $-\mathbf{a}$ came about historically.

Checked terminance. A syllable with checked terminance displays complete obstruction of airflow (without immediate release) at the end of the word. Rimes which end in checked stops (i.e., /-p', -t', $c^{\top},-k^{\top} /$ ) always have checked terminance. When, however, the final segment is a sonorant /-m, $-\mathbf{n},-\mathbf{n},-\mathbf{y},-\mathbf{V},-\mathbf{j},-\mathbf{r},-\mathbf{l},-\mathbf{w} /$, the Kri system allows a distinction between checked and voiced terminance values (in addition to the voiceless terminance just outlined for $/ \mathrm{V}$, $-\mathbf{j},-\mathbf{r},-\mathbf{l},-\mathbf{w} /)$. With voiced terminance, a final sonorant phoneme is simply realized as a sonorant final (as in [ $\mathbf{p}^{\circ} \mathrm{x}$ ] 'cow', [i’a:m] 'sugar cane', [6yaj] 'tea scoop'), while with checked terminance, a sonorant final segment is post-glottalized (as in [ $\left.\mathbf{p}^{0} \mathbf{x}^{2}\right]$ 'father's younger brother', [iْg:m'] 'cry', [6yaj'] 'time, occasion'). Phonetically, for sonorant finals, checked terminance simply means the presence of a glottal stop. However, to reiterate a point made 
Phonology and sketch grammar of Kri, a Vietic language of Laos / CLAO 38(2009) 3-69

above, while in phonetic terms these syllables do have a glottal stop final, this glottal stop does not occupy a segmental 'slot', but represents a rime-level laryngeal distinction in terminance. Our analysis is supported by phonological principles of parsimony and preservation of symmetry. We do not yet know of compelling reasons to prefer the obvious alternative, namely that final glottalization and final devoicing could be represented as corresponding to distinct final segments / $/ 2 /$ and $/ / h /$, implying clusters in final position.

We now supply some examples showing contrasts involving final checked terminance. We have already supplied a good number of examples of checked terminance in presenting the three-way terminance distinctions for oral sonorants, above. But since $-w$ showed so few cases, we add further examples here focusing on the voiced/checked distinction for $-w$ :

(27) Voiced

tew 'to wear'

c'gw 'speak'

kcaw 'rich'

$$
\begin{aligned}
& \text { Checked } \\
& \text { tew' 'tree sp.' } \\
& \text { Chkw' 'wood strips' } \\
& \mathrm{CQW}^{\text {? }} \text { ' } \mathrm{pl} \text { INCL' }
\end{aligned}
$$

Since nasals do not show voiceless terminance, there is only a twoway terminance distinction in final nasals. Here are examples of the voiced versus checked terminance contrast for final nasals:

(28)

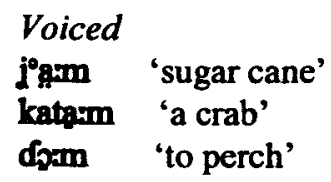

\section{(29) Voiced}

Checked

j'gm? 'cry'

spm? 'eight'

lam? 'to steal'

k6gen 'washbowl'

palygn 'earthworm'

\section{Checked}

6gan? 'village'

lym? 'to cross under' 
(30) Voiced

6up 'ashes, dust'

logn 'be pointed'

tan 'to weave'

(31) Voiced

pan 'to signpost a swidden' cal'on'tree sp.'

con 'tree sp.'

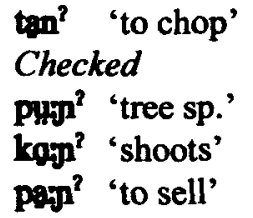

\section{Checked}

marn' 'elder brother'

kal'ogy' 'a loop'

$\operatorname{com}^{2}$ 'salty'

Note that there is also a type frequency asymmetry for the nasal terminance types:

\begin{tabular}{llll}
\hline $\begin{array}{l}\text { Final } \\
\text { segment }\end{array}$ & $\begin{array}{l}\text { Total type } \\
\text { occurrences }\end{array}$ & $\begin{array}{l}\text { w/ Voiced } \\
\text { terminance }\end{array}$ & $\begin{array}{l}\text { w/ Checked } \\
\text { terminance }\end{array}$ \\
\hline$-\mathbf{m}$ & 165 & $99(60 \%)$ & $66(40 \%)$ \\
$-\mathbf{n}$ & 191 & $109(57 \%)$ & $82(43 \%)$ \\
$-\mathbf{n}$ & 67 & $29(43 \%)$ & $38(57 \%)$ \\
$-\mathbf{n}$ & 440 & $276(63 \%)$ & $164(37 \%)$ \\
\hline
\end{tabular}

Table 4. Type frequencies of final nasals and their occurrence with different terminance distinctions (as absolute number and as percentage of all type occurrences of that final segment with the relevant terminance value).

The relative frequencies of voiced versus checked terminance for final nasals look fairly consistent (in the 60/40 range), with the exception of $-\mathrm{n}$, which shows the reverse pattern. Post-glottalization occurs in nearly half of all nasal-final words, showing that it is not a marginal feature, but a robust phonological feature of the Kri lexicon. Further work is needed in onder to understand how it is that the feature of lexically specified post-glottalization could have originally developed. A conceivable hypothesis might be that postglottalization has its source in borrowings from languages like Sek or Lao varieties, since glottalization is often a predictable feature of 
Phonology and sketch grammar of Kri, a Vietic language of Laos / CLAO 38(2009) 3-69

specific lexical tones in those languages. However, such an account offers little promise, due to the fact that post-glottalized $-\Omega^{2}$ is common in $\mathrm{Kri}$ (indeed more common than the non-glottalized version): the Tai languages do not have palatal finals, and could therefore not have contributed to the Kri pattern here.

Summary of terminance. We now summarize the discussion of terminance distinctions. There are three terminance values: checked, voiced, and voiceless. Not all finals (Table 2) can occur with all three terminance values. Final stops show no terminance contrast (they are always checked); final nasals show a two-way contrast between checked and voiced terminance; and final oral sonorants show a three-way contrast between checked, voiced, and voiceless terminance. This gives the following full set of rime endings:

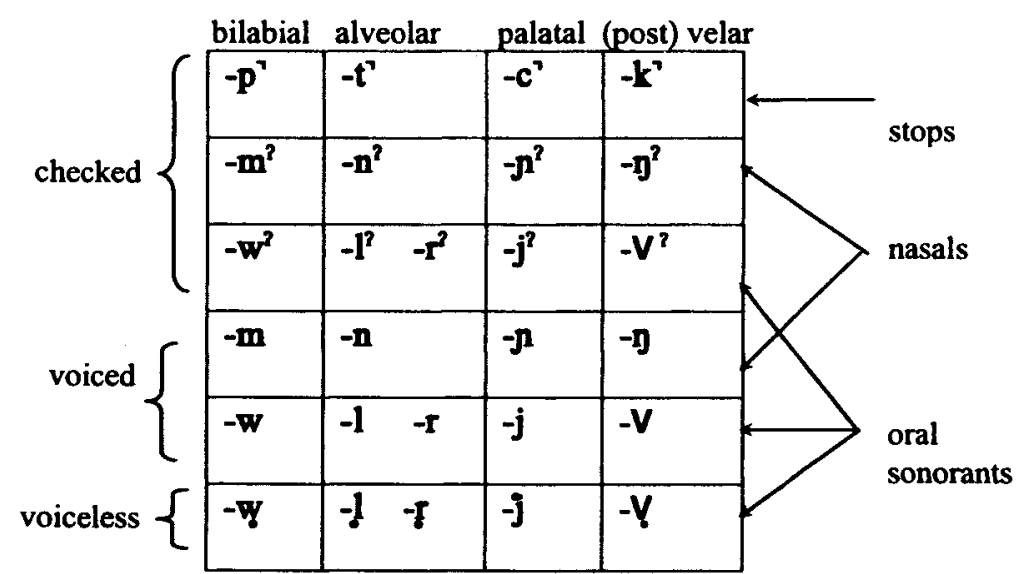

Table 5. Possible rime endings ( $27=13$ checked, 9 voiced, 5 voiceless).

A consequence of this terminance analysis is that many of the large number of rime endings listed in Table 5 are not to be considered as composed of distinct segmental units. Specifically, the two rows of 
nasals and the three rows of oral sonorants each reduce to one, in segmental terms. The contrasts arise from a combination of a particular final consonant with a particular rime-level terminance value. This analysis is partly motivated by the relative cost of the alternatives. One alternative would be to add a set of nine new final segmental units in a post-glottalized series (with no equivalents in the system of initials), ${ }^{12}$ plus a set of five new phonemic segmental units in a voiceless series (with no equivalents in the system of initials), as listed in Table 5. Another alternative would be to treat the final glottal stop and $h$ as distinct segments in the system of finals, thereby allowing final consonant clusters. However, there would then be only two permissible segments in the second position of such a cluster, namely $\left[-{ }^{-}\right]$and [-h], making it a somewhat unbalanced system. Furthermore, it is no coincidence that these are both laryngeal, a feature strongly associated with suprasegmentals (cf. Diffloth 1974). To treat these as final clusters would be a major departure from the otherwise required phonotactic template (see below). By treating terminance as a non-segmental phenomenon, our analysis avoids these problems.

\subsection{Vowels}

As in many other Austroasiatic languages of mainland Southeast Asia, Kri words may be monosyllabic or disyllabic. When a word is disyllabic, the first of the two syllables will be heavily restricted. We use the traditional term minor syllable to refer to the first part of words which have an iambic prosodic pattern (e.g., [ka-] in [katom] 'crab', [pu-] in [pu'len'] 'fruit'). Some key features of the minor syllable are: reduced stress, lack of vowel length distinction, a much reduced system of vowel quality contrasts, and absence of independent register distinction (see below). The major syllable (i.e., the rest of the word) receives

\footnotetext{
${ }^{12}$ This is a solution currently adopted in Vietic historical reconstruction (Ferlus
} 1998). 
primary word-level stress, and shows the full range of contrasts in the vowel system (quality, length, register), just as a monosyllabic word does. ${ }^{13}$

To describe the vowel system of Kri, it is necessary to begin with the site of its greatest elaboration, the major syllable. As we shall later see, the minor syllable vowels constitute a radically reduced system.

\subsubsection{Major syllable vowel nuclei}

There is a fundamental distinction in Kri major syllables between long and short vowels. The system of long vowels shows a greater number of quality distinctions than the system of short vowels. Long vowels also show greater type frequency: In words with types of syllable where vowel length contrast is possible, $67 \%$ of these words have long vowels. ${ }^{14}$ In order to illustrate the full set of contrasts in the vocalic system, we begin then with the long vowels.

We observe 18 long vowel distinctions in Kri:

\footnotetext{
${ }^{13}$ The term 'sesquisyllabic' was introduced by Jim Matisoff for the description of a common type of word structure in languages of mainland Southeast Asia. We do not use the term here, because we want to avoid any confusion resulting from the subsequent inconsistent application of the term to (at least) two quite distinct kinds of situation in which a word can be said to begin with a so-called half syllable: 1 . where the 'half syllable' is not phonologically a syllable at all, but is the phonetic result of an epenthetic vowel appearing in an initial cluster, and 2 . where the 'half syllable' is phonologically a syllable that shows significant phonotactic constraints compared to what we call the major syllable. Moreover, we want to avoid the term's unfortunate suggestion of the existence of 'half syllables' in a domain where units are abstract and discrete, not measurable on a linear scale of halves or thirds.

${ }^{14}$ With stop final, short $=224$, long $=400$; with nasal, hotic, glide finals (not $-\mathrm{Y}$ ), short $=444$, long $=980$; i.e., 668 short versus 1380 instances of long vowels where contrast is possible.
} 
Enfield N.J. \& Diffloth G. / Cahiers de Linguivtique - Asie Orientale 38(2009) 3-69

\begin{tabular}{|c|c|c|c|}
\hline High & $\begin{array}{l}\text { Front } \\
\text { j: } \\
\text { it }\end{array}$ & $\begin{array}{l}\mathbf{j} \\
\mathbf{b} \\
\mathbf{v}\end{array}$ & $\begin{array}{l}\text { Back } \\
\text { y: } \\
\text { o: }\end{array}$ \\
\hline Low & 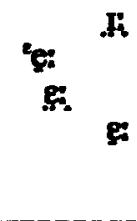 & 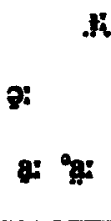 & $\mathfrak{g}^{x}$ \\
\hline
\end{tabular}

Table 6. Long vowels, phonetically analyzed

Here are some sets of illustrative (near) minimal contrasts between these long vowels:

(32) Front vowels

$\begin{array}{ll}\text { pikk' } & \text { 'a tadpole' } \\ \text { p'pt' } & \text { 'to plant' } \\ \text { Vak' } & \text { '(to) work' } \\ \text { sav'ek' } & \text { 'to comb back' } \\ \text { peg y } & \text { 'to be dear' } \\ \text { cavgek' } & \text { 'peel sth. apart' } \\ \text { cavakk' } & \text { 'fish sp.' }\end{array}$

(33) Back vowels

$\begin{array}{ll}\text { thy: } & \text { 'bamboo sp.' } \\ \text { clio: } & \text { 'buffalo' } \\ \text { kalu: } & \text { 'fruit sp.' } \\ \mathbf{k l}: & \text { 'star' } \\ \mathbf{k}{ }^{\circ} \mathbf{x} & \text { 'fish sp.' } \\ \text { culg: } & \text { 'palm sp. (licuala sp.)' }\end{array}$

(34) Central vowels

$\begin{array}{ll}\text { c'ç: } & \text { 'now' } \\ \text { ho: } & \text { 'broken' } \\ \text { mly } & \text { 'afraid' }\end{array}$


Phonology and sketch grammar of Kri, a Vietic language of Laos / CLAO 38(2009) 3-69

$\begin{array}{ll}\text { murg: } & \text { 'disgusted' } \\ \text { tul':日: } & \text { 'weird' } \\ \text { kalg: } & \text { 'bamboo sp.' }\end{array}$

In comparison to other languages of the world, the set of contrasts represented here shows unusually fine phonetic distinctions. There is evidence, however, for a simpler underlying system. We can group these 18 vowels into 9 pairs, where the two members of each pair contrast in terms of phonation:

For each pair, as grouped by dotted ellipses in Table 7, one member has a relatively breathy or heavy phonation type, the other has a relatively tight and clear or light phonation type.

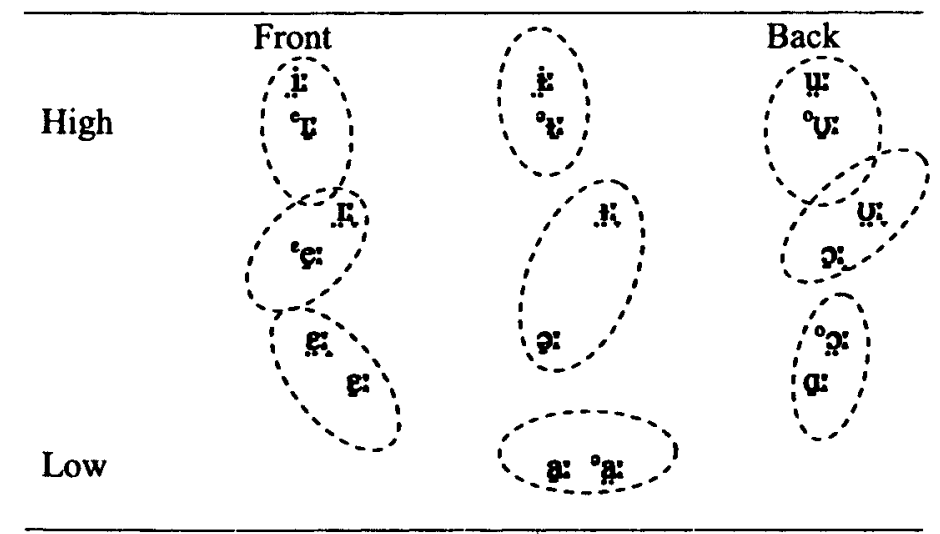

Table 7. Long vowels, showing vowels paired by register

This type of phonation-based register distinction is common in Austroasiatic languages. In phonological terms, we refer to this distinction as register (Henderson 1952, Gregerson 1976, inter alia). We use the terms 'heavy' and 'light', instead of, for example, 'breathy' and 'clear', because there is more than merely phonation involved in this 2-way distinction between types of syllable. We have not yet carried out instrumental phonetic studies of the register 
distinction, but our auditory impression is that words in heavy register show lower overall pitch, longer rime duration, and later voice onset (if the major initial consonant is unvoiced) than words in light register. In addition, vowels in heavy register words are raised relative to the same vowels in light register counterpart words. The register distinction is therefore a package of several phonetic features, and our use of the terms 'light' and 'heavy' reflects this by not picking out voice quality as the operative feature. ${ }^{15}$

Native speakers have a folk category of 'heavy' versus 'light' in reference to the language's sound system, but this is not consistently applied to the phenomenon of phonological register. There are three native applications of the term: (1) to the lexically specified phonological register distinction (heavy [ci.'] 'elder sister' versus tight [ [cel] 'louse'); (2) lexically specified terminance distinction, especially where this determines the presence versus absence of a final glottal stop in a syllable (checked terminance [?akg:'] 'fish' versus voiced terminance [ka; 'chicken'); (3) dialect differences in pronunciation of the same word (any two cognates spoken in Kri vs. the related dialect Phòòngq).

In addition to the basic difference in phonation type, there are noticeable vowel quality differences between heavy and light counterpart vowels, as shown in Table 7, above.

(35) Some minimal pairs contrasting in register

\begin{tabular}{|c|c|c|c|}
\hline 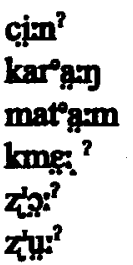 & $\begin{array}{l}\text { 'nine' } \\
\text { 'sand' } \\
\text { 'son-in-law' } \\
\text { 'thumb' } \\
\text { 'clear' } \\
\text { 'fence' }\end{array}$ & 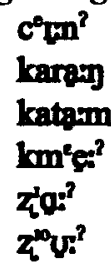 & $\begin{array}{l}\text { 'cooked' } \\
\text { 'sunshine' } \\
\text { 'crab' } \\
\text { 'female (chicken)' } \\
\text { 'pig basket' } \\
\text { 'to know' }\end{array}$ \\
\hline
\end{tabular}

${ }^{15}$ It is also worth noting that while the register distinction is a significant one, in fact the difference is auditorily very subtle, and it took us a long time to learn to hear the distinction clearly. Hearing the difference is a kind of knack, similar to the case of tones. 
Phonology and sketch grammar of Kri, a Vietic language of Laas / CLAO 38(2009) 3-69

Emerging from the array in Table 7 is an orderly pattern of nine heavy-light pairs, giving 18 vowels in all. The pattern is easily recognizable as the 9-position system widely found in languages of the mainland Southeast Asia area (cf. Enfield 2005:182-184):

\begin{tabular}{|c|c|c|c|c|}
\hline & & Front & Central & Back \\
\hline \multirow{2}{*}{ High } & Heavy & i & I: & y: \\
\hline & Light & ${ }^{\circ} \mathbf{E}$ & ${ }^{\circ} \mathbf{b}$ & ${ }^{0} \mathbf{W}:$ \\
\hline \multirow{2}{*}{ Mid } & Heavy & . & $x$ & $U_{4}$ \\
\hline & Light & ex: & 9: & $\mathbf{p}$ \\
\hline \multirow{2}{*}{ Low } & Heavy & ?: & g & ${ }^{0}$ \\
\hline & Light & e: & a: & $\boldsymbol{\alpha}$ \\
\hline
\end{tabular}

Table 8. Long vowels laid out in a standardized 9-place system

The set of short vowels is significantly reduced in comparison to the long vowels, in having fewer members, lower type frequency, and more restricted phonotactics (see below):

\begin{tabular}{|c|c|c|c|c|}
\hline & & Front & Central & Back \\
\hline \multirow{3}{*}{ Non-Low } & Heavy & 1 & F & $\mathbf{p}$ \\
\hline & & 9 & & 9 \\
\hline & Light & & $\rho$ & \\
\hline \multirow{2}{*}{ Low } & Heavy & e. & 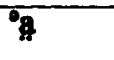 & $?$ \\
\hline & Light & e & 8 & $\mathbf{a}$ \\
\hline
\end{tabular}

Table 9. Short vowels 
Of note here is that the two high central short vowels $\dot{j}$ and $\rho$ are spaced further apart than their front and back counterparts. For the front and back vowels, comparing the short and long vowel systems, it is as if the mid vowel pairs are absent. The low central pair ${ }^{\circ} \mathrm{a}$ and $\mathrm{a}$ is also present as in the long vowel system. For the mid and high central vowels, however, while the heavy high central short vowel is more or less of the same height as its counterpart in the long vowel system, the light high central short vowel $\supseteq$ is more similar in quality not to its counterpart the light high central long vowel, but to the light MID central short vowel, i.e. schwa. The behavior of this mid non-low short vowel pair prevents us from making the general statement that in the short vowel system the mid vowels are simply absent.

An advantage of taking the register distinction as primary is that we can then make some generalizations about the phonetics of vowel quality. For example, any heavy register vowel will be higher (or partially higher) in the vowel space than its light counterpart. One consequence of this is that the maximally high

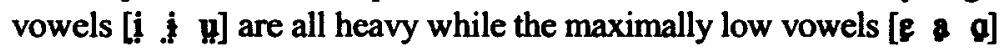
are all light. These maximally high and maximally low vowels are all steady state vowels, while their counterparts - high light [" $\left.{ }^{\circ} \mathrm{ot}{ }^{\circ} \mathrm{o} / \mathrm{c}\right]$ and low heavy [ $\mathrm{g}$. ${ }^{\circ} \mathrm{g}{ }^{\circ} \mathrm{g} ;$ ] - all of which are closer to mid in height, mostly have noticeably distinct onsets ([ $[\mathrm{s}$.$] being the exception).$ These onsets are even closer to mid in height.

Had we focused on vowel quality rather than phonation as a criterion for pairing, the result would have failed to capture the system concisely. Looking at Table 6 , one might have thought that

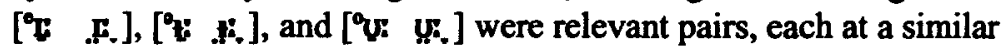
height and each differing in phonation. This, however, would have left a number of vowels unpaired, and would not have cleanly captured the set as a whole. In addition, there is evidence from loanwords that our pairings are correct. Loans from Lao will be assigned to one of the two registers in Kri, with apparently even distribution: out of 188 Lao loans, $57 \%$ have light register. 
Phonology and sketch grammar of Kri, a Vietic language of Laas /CLAO 38(2009) 3-69

Depending on the register, the phonetic quality of the vowel in a Kri word can be significantly different from that of the Lao source word. For example, the vowel in Kri [le: $\left.w^{2}\right]$ (a perfective marker) is phonetically much higher than the vowel in its Lao source [le:w"1]; in fact, so much higher that it sounds closer to the next vowel up in the Lao vowel space: /e/ as in [leww3] 'to fight'. Similarly, the Kri word [ $\mathbf{m}^{\text {e }} \mathrm{gk}$ '] 'to like' is borrowed from Lao [mak ${ }^{\text {st }}$ ] 'to like', with a significantly higher vowel, near to schwa. The vowel of the source word in Lao is phonetically more similar to that of another Kri word, the light register [mak] 'to wear'. By contrast, Kri lak' 'sneaky', borrowed from Lao lak ${ }^{\text {th }}$ 'to steal, to do secretly' has LIGHT register, and thus ends up with a vowel which is identical with that of the Lao source. This provides some support to the idea that each of the pairs shown in Table 7 correspond to a single underlying point in the vowel space. Or to put it another way, it is as if each heavy/light pair of Kri vowels occupies a single 'bin', each such bin corresponding to a single Lao vowel.

There are three diphthongs, all of which seem to be found in borrowings. They can occur in both open and closed syllables. These are low in lexical type frequency (all together, 42 out of 2778 words have one of these diphthongs; less than 2 percent):

\begin{tabular}{lll}
\hline Front & Central & Back \\
\hline i⿱ & ig & 뵤 \\
\hline
\end{tabular}

Table 10. Diphthongs

There is no evidence for a contrastive register distinction in the diphthongs. They are reliably pronounced with heavy register (perhaps unexpected given that heavy is the marked register - see below). Attempted elicitation of register distinction did not yield recognition of a heavy-light contrast by speakers. This contrasts with the complete ease with which speakers recognize and produce register distinctions for regular vowels. Note that there are a 
Enfield N.J. \& Diffloth G. / Cahiers de Linguistique - Asie Orientale 38(2009) 3-69

number of cases which look like diphthongs, but which we treat as sequences of vowel plus glide $a j, a w$, etc.), analyzing these as VC strings.

2.3.2 On the lack of relation between register and initial consonant class in $\mathrm{Kri}$

There is a type frequency asymmetry in the heavy versus light register distinction in Kri. About two-thirds of words in our lexicon are light; 1892 vs. 887 (that is, $68 \%$ of words have light register). In related languages, register distinctions often show radically different distributions depending on classes of initial consonant, especially regarding implosives and glottal stops. For example, in modern Mon, words with a voiceless stop initial such as t- may have either clear or breathy register, with roughly equal type frequency, while words with an implosive stop initial such as of show almost exclusively clear register. This has a straightforward historical explanation: * $\&$ conditioned clear register, whereas modern t- has two historical sources, *d- (which conditioned breathy register) and *t- (which conditioned clear register). Similarly, Mon words which begin with glottal stop will be almost exclusively clear in register. This does not appear to be the case in $\mathrm{Kri}$, with glottal stops and implosive initial consonants showing a similar relation to register as other types of initial consonant: for example, in the set of words with voiceless stop initial t-, 68\% (154 vs. 72) have light register; in the set of words with implosive stop initial of, 76\% (122 vs. 38) have light register; in the set of words with glottal stop initial 2-, 73\% (60 vs. 22) have light register. These figures are in line with the overall distribution of register in the language ( $68 \%$ of all words have light register). 
Phonology and sketch grammar of Kri, a Vietic language of Laas / CLAO 38(2009) 3-69

\subsubsection{Minor syllable vowel nuclei}

The minor syllable vowels constitute a radically reduced system, with the following properties:

- only three vowels occur: -a-, -i-, -u-

- there is no vowel length distinction (always short/unstressed)

- there is no independent register distinction ${ }^{16}$

While all words have major syllables, minor syllables are relatively infrequent. Around a third of all words have a minor syllable $(998 / 2778=36 \%)$. Of these, many do not have a vowel, but an $-r-(203 / 998=20 \%)$. Of those minor syllables which do have a vowel, most have $-a-(562 / 795=71 \%)$, while the other two are significantly less frequent $(-u-177 / 795=22 \%,-i-56 / 795=7 \%)$.

\subsection{Phonotactics}

2.4.1 Phonotactic template for the word

Here is a template for the possible types of Kri word, in terms of segmental and suprasegmental components:

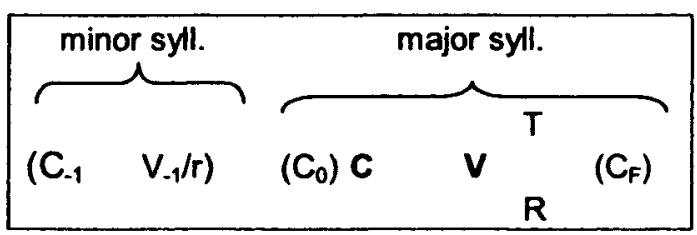

Figure 2. Word template $(\mathrm{C}=$ consonant, $\mathrm{V}=$ vowel, $\mathrm{R}=$ register, $T=$ terminance, $F=$ final)

\footnotetext{
${ }^{16}$ The arguments presented in sections 2.3.2 and 2.3.3 support the view that register is a property of the rime alone.
} 
The surface realization of each word is a product of (a) a string of segments, (b) a terminance value, (c) a register value. Here are a few examples, making this explicit:
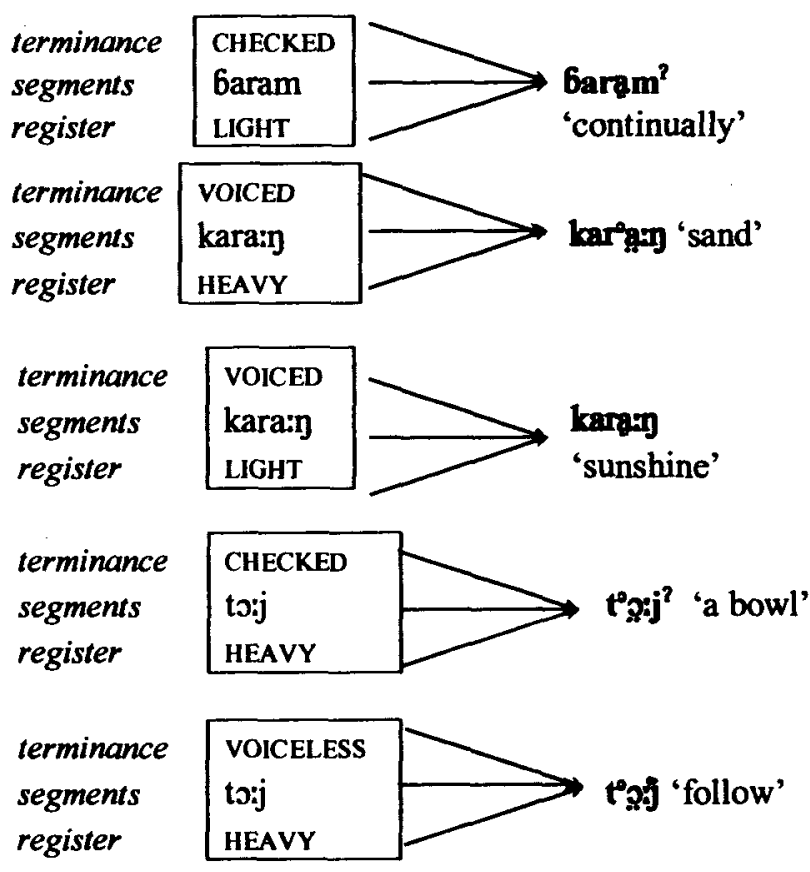

In this way, all words must have a value for terminance and register, and must have segmental material specified for at least the slots $C$ and $V$. Remaining slots in the segmental template in Figure 2 may or may not be filled. To list the possibilities, we distinguish firstly between words with a single segment in the major initial slot and those with a $\mathrm{C}_{0} \mathrm{C}$ sequence: 
Phonology and sketch grammar of Kri, a Vietic language of Laos / CLAO 38(2009) 3-69

(41) $\mathrm{CV}\left(\mathrm{C}_{F}\right)$ type:

CV cq: '1pl.excl', cq:? 'dog', zq: 'dry', 6q: 'to vomit'

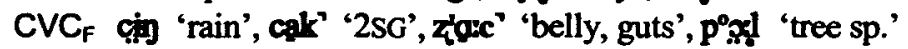

(42) $\mathrm{C}_{0} \mathrm{CV}\left(\mathrm{C}_{F}\right)$ type:

$\mathrm{C}_{0} \mathrm{CV}$ kra: 'old', 6ra:? 'machete', 10d ' $\mathrm{F}$ 'sambar deer', simp:" 'breed'

$\mathrm{C}_{0} \mathrm{CVC}_{\mathrm{F}}$ praw 'cross', $f$ 'log' 'hang net', 6lew 'turtle sp.', toger 'luck', $f^{\circ} \mathrm{hpg}^{3}$ 'hair on end'

Secondly, for both of these types, there may be a minor syllable preceding. Words of the type $\mathrm{CV}\left(\mathrm{C}_{F}\right)$ with a preceding minor syllable are common, as in the following examples: ${ }^{17}$

(43) $\operatorname{CV}\left(C_{F}\right)$ type with minor syllable preceding:
$\mathrm{crCV}$
2akg:' 'fish', tara: 'moon', 6rica: 'tree sp.', cady. 'to sit'
cVCVC $_{F}$ kargay 'sand', kafary" 'seed', trfarm? 'walk', pacert 'to break off'

Words of the type $\mathrm{C}_{0} \mathrm{CV}\left(\mathrm{C}_{\mathrm{F}}\right)$ with preceding minor syllable are rare. In our current vocabulary of 2778 words, we have one word with the structure $\mathrm{CvC}_{0} \mathrm{CV}$, and three cases of $\mathrm{CVC}_{0} \mathrm{CVC}_{\mathrm{F}}$ :

(44) $\mathrm{C}_{0} \mathrm{CV}\left(\mathrm{C}_{\mathrm{F}}\right)$ type with minor syllable:

$\mathrm{CVC}_{0} \mathrm{CV}$ sakla: 'fish scale'

$\mathrm{CVC}_{0} \mathrm{CVC}_{\mathrm{F}}$ kapr'Ut' 'beetle sp.', kaplan 'bamboo sheath',

kapl'un 'rabbit'

\footnotetext{
${ }^{17}$ For convenience here, we use lower case letters for the $C_{-1} V_{-1}$ of the minor syllable.
} 


\subsubsection{Distributional constraints of segments}

There are restrictions on the distribution and combination of segments within the template supplied in Figure 2. The situation regarding vowels is straightforward, as already described above: only $a, i$, and $u$ may occur as $V_{-1}$, while any vowel may occur in the $V$ slot. Note that if $V$ is short, $C_{F}$ must be realized. Recall that we have chosen not to analyze the laryngeals (glottal stop and $h$ ) as final consonants in the segmental template, and accordingly there are no words with short vowel and glottal stop or $h$ final.

In all words, the $C_{F}$ position may be filled by any of the final consonants (Table 2). In $\mathrm{CV}\left(\mathrm{C}_{\mathrm{F}}\right)$ words, the $\mathrm{C}$ position may be filled by any of the major initial consonants (Table 1). In words with a pre-C consonant, we have not yet found words with $h, j$, or $v$ in either $\mathrm{C}_{0}$ or $\mathrm{C}_{-1}$ position. A pre-C consonant will almost always be a voiceless unaspirated stop $/ \mathbf{p}, \mathbf{t}, \mathbf{c}, \mathbf{k}, \mathbf{Z} /$ or $/ \mathbf{s} /$. There are a few exceptions but the numbers are small. In pre-C position, aspirated stops are rare (with only a few cases of kh-), as are implosives, of and $f$. However, 6 - is an exception, for which we have over 40 examples (mostly before $\mathbf{r}$ and $\mathbf{l}$, also $\mathbf{s}$ ). This is relevant to previous treatments of implosives in related languages as being clusters consisting of a glottal stop plus a stop, called 'preglottalized stops'. For example, Thompson (1987:23) describes the voiced implosives in Vietnamese as 'preglottalized and often imploded', analyzing [6-] and [f] ] as / $/ \mathrm{p}-/$ and $/ \mathrm{ft}-/$. This would create problems in the $\mathrm{Kri}$ case, due to the occurrence of initial strings like 6r-, 61-, and 6- (e.g.,

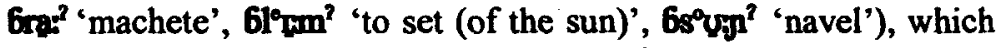
would imply three-segment initial clusters / $/ \mathrm{pr}-1$, /pl-/, and /Pps-/.

There are very few cases in which aspirated stops occur non word-initially (i.e., in $\mathrm{C}$ position where there is pre-C material): our only cases are ck' 'gn' 'really', cuktip' 'to lever', ck hail 'cross-beam' (notably, all involving the same segments in pre-C and $C$ positions). Nasals in $\mathrm{C}_{0}$ position are syllabic before homorganic stops, laterals, and nasals (note the resulting gemination in examples ( $f$ ) and $(g)$ ): 
Phonology and sketch grammar of Kri, a Vietic language of Laas / CLAO 38(2009) 3-69

(45)
(a) mbat' 'sweet'
(b) nl'v:? 'palm sp.'
(c) nt?: 'oil'
(d) $\mathrm{n} \mathrm{carr}^{2}$ 'mat'
(e) I kign 'a wave'
(f) mmgen? 'sweet'
(g) nngy' 'heavy'

In our only case in which a nasal in $\mathrm{C}_{0}$ position precedes $\mathbf{h}$, it is also syllabic:

(46) ṇhgm? 'fragrant'

In other conditions, an epenthetic schwa appears between the $C_{0}$ nasal and $\mathrm{C}$ :

(47) (a) jegr 'fall through something'

(b) J'ron 'River name'

(c) molg:c' 'bland'

(d) milend 'person'

(e) mtre 'in-laws'

2.4.3 Six rime types, as defined by terminance and register

The intersection of register (with two values) and terminance (with three values) yields six distinct rime types in Kri, and these six rime types show distinct type frequencies:

\begin{tabular}{|c|c|c|c|}
\hline & & \multicolumn{2}{|c|}{ register } \\
\hline & & heavy & light \\
\hline & checked & HEAVY-CHECKED & LIGHT-CHECKED \\
\hline erminance & voiced & HEAVY-VOICED & LIGHT-VOICED \\
\hline & voiceless & HEAVY-VOICELESS & LIGHT-VOICELESS \\
\hline
\end{tabular}

Figure 3: The six Kri rime types, defined by intersections of terminance and register distinctions 


\begin{tabular}{rlll} 
& & \multicolumn{2}{c}{ register } \\
& & heavy & light \\
terminance $=1393(50 \%)$ & 400 & 993 \\
& voiced $=1132(41 \%)$ & 412 & 720 \\
& voiceless $=253(9 \%)$ & 77 & 176 \\
Total & $889(32 \%)$ & $1889(68 \%)$
\end{tabular}

Figure 4: Type frequencies of the different rime types from our list of 2778 words

These frequencies may appear to be unbalanced, but a closer look reveals that each category is well represented, once viewed within the context of the larger system. None of the rime types can be regarded as marginal.

First, as already noted above, there is an across-the-board imbalance between rimes of heavy and light register: that is, irrespective of terminance value, light rimes outnumber heavy rimes by about two to one. The total ratio of light rimes in our sample of 2778 words is $68 \%(n=1889)$. Within all checked terminance rimes, light register rimes make up $71 \%(n=993)$; within all voiced rimes, light register is $64 \%(n=720)$; within all voiceless rimes, it is $70 \%(n=176)$. So, the two-to-one ratio of light to heavy register is stable and insensitive to terminance type. This shows that register creates a fundamental dichotomy across the Kri lexicon.

We may now ask why there are differences in absolute frequency between rimes of the three terminance values. The explanation is simple. As laid out in Table 5, above, checked terminance is a possible value for rimes with all 13 final consonants, whereas voiced terminance is possible for only 9 final consonants (stops are excluded), and voiceless terminance for only 5 (stops and nasals are excluded). Let us first compare the ratio of checked terminance rimes to voiced terminance rimes. For checked terminance, at a total of 1393 cases with 13 finals possible, each final consonant occurs on average 107 times. For voiced terminance, at a 
total of 1132 cases with 9 finals possible, each final consonant occurs on average 125 times. Thus, the average occurrence of any final consonant for these two terminance values is of a similar order.

Turning to voiceless terminance, the situation looks different at first blush: there are $\mathbf{2 5 3}$ words with voiceless terminance, where five final consonants are possible. This would suggest an average frequency of 47 instances of voiceless terminance per consonant. However, as shown in Table 3, above, two of these five finals are vanishingly rare (one case of $-\mathbf{y}$ and three cases of $-j$ ), and another two $--r$ and $-j-$ have a single historical origin: *-s. So, not counting the handful of $-w$ and -1 cases, and counting $-r$ and $-j$ together as a single consonant, we obtain a frequency of 127 instances of voiceless terminance per available final consonant, precisely in line with the frequencies for checked and voiced terminance (125 and 107), above.

In sum, taking into account systemic facts about the crosscutting distinctions of register and terminance, we see that the system of six distinct rime types summarized in Figures 3 and 4 shows an even balance across the Kri lexicon. In this and other respects, such a system of suprasegmental distinctions is strongly reminiscent of a lexical tone system. The Kri system is obviously similar to those that set the stage for tonogenesis in Tai languages, Vietnamese, and varieties of Chinese (Maspero 1912, Haudricourt 1946, 1953, 1954, Matisoff 1973, Gage 1985, Norman 1988, Alves 1995, Ferlus 1997, Thurgood 2002, inter alia). However, we want to stress that there is no way to know how the Kri system may develop in the future, nor can it be regarded as 'transitional' in any special sense. Furthermore, while the Kri data will be extremely important for research in comparative Vietic, $\mathrm{Kri}$ is a modern language which has evidently long been developing in its own way (cf. our discussion of voiceless terminance, above). The Kri sound system should not be taken to be 'archaic' or otherwise equal to the system of proto-Vietic. 
Enfield N.J. \& Difloth G. / Cahiers de Linguistique - Asie Orientale 38(2009) 3-69

\subsection{Orthography}

Given the high number of contrasts in the Kri sound system, it is inevitable that a practical orthography will involve nonstandard characters and digraphs. The full inventory of major initial consonants (see Table 1, above) will be transcribed as in Table 11

\begin{tabular}{|c|c|c|c|c|c|c|c|}
\hline \multirow{7}{*}{$\begin{array}{l}\text { voiced (implosive) stops } \\
\text { voiceless aspirated stops } \\
\text { voiceless unaspirated stops } \\
\text { fricatives } \\
\text { nasal sonorants } \\
\text { oral sonorants }\end{array}$} & \multicolumn{7}{|c|}{ labial alveolar retroflex palatal velar laryngeal } \\
\hline & b & d & & & $q i$ & & \\
\hline & pl & th & & $\mathbf{t a r h}$ & & $\mathbf{k h}$ & \\
\hline & p & $\mathbf{t}$ & & tar & c & $\mathbf{k}$ & $\mathbf{q}$ \\
\hline & & $\mathbf{s}$ & & & & gh & h \\
\hline & $\mathbf{m}$ & $\mathbf{n}$ & & & $\tilde{\mathbf{n}}$ & $\mathbf{n g}$ & \\
\hline & $\mathbf{v}$ & 1 & $\mathbf{r}$ & & $\mathbf{j}$ & & \\
\hline
\end{tabular}

Table 11. Initial consonants, orthographically

The finals will be transcribed as in Table 12 (cf. Table 2, above):

\begin{tabular}{|c|c|c|c|c|c|}
\hline \multirow{3}{*}{ stops } & \multirow{3}{*}{$\begin{array}{l}\text { checked } \\
\text { nasal }\end{array}$} & bilabial & alveolar & palatal & (post) velar \\
\hline & & $\mathbf{p}$ & $\mathbf{t}$ & c & $\mathbf{k}$ \\
\hline & & $\mathbf{m}$ & $\mathbf{n}$ & 站 & ng \\
\hline sonorants & oral & $\mathbf{w}$ & $1 r$ & $\mathbf{j}$ & \\
\hline
\end{tabular}

Table 12. Final consonants, orthographically.

Finals with checked terminance listed in Table 5, above, are represented in the orthography with $q$ after the appropriate sonorant (giving checked terminants - $\mathbf{V q},-\mathbf{m q},-\mathbf{n q}$, -ñq, -ngq, -wq, -lqq, -rq, and $-\mathbf{j q}$ in contrast to voiced terminants $-\mathbf{V},-\mathbf{m},-\mathbf{n},-\mathbf{n},-\mathbf{n g},-\mathbf{w},-\mathbf{l},-$ $\mathbf{r}$, and $-\mathbf{j}$ ). Finals with voiceless terminance listed in Table 5 , above, are represented in the orthography with $h$ after the appropriate oral sonorant (giving voiceless terminants $-\mathrm{Vh},-\mathbf{w h},-\mathbf{l h},-\mathbf{r h}$, and $-\mathbf{j h}$ in 
contrast to voiced terminants $-\mathbf{V},-\mathbf{w},-\mathbf{I},-\mathbf{r}$, and $-\mathbf{j})$. This is a purely practical representation, and we remind the reader that our analysis does not recognize final glottal stop and $h$ (here as $-q$ and $-h$ ) to be distinct segments. Rather, they are outcomes of particular terminance values.

The basic nine vowel symbols are equivalent to their values in Quốc Ngữ script used for Vietnamese (Thompson 1987:18ff):

\begin{tabular}{lll}
\hline $\mathbf{i}$ & $\mathbf{u}$ & $\mathbf{u}$ \\
$\hat{\mathbf{e}}$ & $\mathbf{0}$ & $\hat{\mathbf{o}}$ \\
$\mathbf{e}$ & $\mathbf{a}$ & $\mathbf{0}$ \\
\hline
\end{tabular}

Table 13. Basic vowel symbols, orthographically

The two-way split in phonological register (heavy versus light) across the nine vowels is marked by means of a diacritic (a grave accent above the vowel) for heavy register. Light register is left unmarked, since it is statistically predominant (see Figure 4, above). So, the vowel "a" will appear as heavy ì or light a. This derives 18 distinct vowel symbols, shown in Table 14.

\begin{tabular}{lll}
\hline $\mathbf{i}$ & ù̀ & ù \\
$\mathbf{i}$ & $\mathbf{u}$ & $\mathbf{u}$ \\
$\hat{\mathbf{e}}$ & ò & ò \\
$\hat{\mathbf{e}}$ & $\mathbf{o}$ & $\hat{\mathbf{o}}$ \\
& & $\mathbf{2}$ \\
$\grave{\mathbf{e}}$ & $\mathbf{a}$ & $\mathbf{o}$ \\
$\mathbf{e}$ & $\mathbf{a}$ & $\mathbf{0}$ \\
\hline
\end{tabular}

Table 14. Orthographical conventions for basic vowel symbols, split into two registers with grave accent marking heavy register and light register unmarked. 
Long vowels are marked with double vowel symbol (i.e., short a versus long aa). Diphthongs are always marked as heavy, since they are usually pronounced that way (as ì̀, ùà and ừà). In subsequent sections of this article, all Kri words will be written using this orthography.

\section{MORPHOLOGY}

Kri has no inflectional morphology (i.e., person, number, gender, case), but does have a modest amount of essentially nonproductive derivational morphology. The derivational morphology of $\mathrm{Kri}$ is more elaborate than is found in heavily isolating neighboring languages like Lao or Vietnamese, but significantly less than in morphologically rich cousins like $\mathrm{Kmhmu}$ (Northern Mon-Khmer, Suwilai 1987) or Semelai (Aslian, Kruspe 2004). We note tantalizing correspondences in the lexicon such as paañ ' 'sell' versus maañq 'borrow', and slaac 'slip' versus haac 'slippery' while these seem to suggest ertswhile morphological relatedness, if there is any such relation it is no longer generally visible or productive. Other cases look like clearer candidates for morphological derivation but we only have one such case: e.g., puin putêêngq 'greeting' (cf. têêngq 'arrive'). Yet other cases resemble otherwise existing morphology, but the semantic relations are not consistent with those cases: e.g., kpôôh 'a handwidth (across palm, including thumb)' versus kapôôh 'to speed up rice-pounding when working as a team' ( $c f$. the two -a- infixes described below). In the following section, we list a few of the more regular-looking derivational morphemes, all of which are infixes.

\subsection{Infixes}

Infixes in Kri have particular consequences for syllable structure of the resulting word: they always result in the creation of 
Phonology and sketch grammar of Kri, a Vietic language of Laas /CLAO 38(2009) 3-69

a minor syllable. We discuss three cases: in the first two, the process of infixation is only accessible to words with $\mathrm{C}_{0} \mathrm{C}$ onsets.

\subsubsection{Causative infix $-a-$}

The causative infix - $a$ - can be inserted into words with $\mathrm{C}_{0} \mathrm{C}$ onsets. The infix then occupies the $v_{-1}$ slot and thereby creates a minor syllable. The erstwhile $C_{0}$ ends up in the new $C_{-1}$ slot. The function of this infix is to turn an intransitive verb into a transitive verb, adding a controller/agent participant:

(48) (a) trùùm - to be on its face

taruium - to put something on its face

(b) praang - to cross over (e.g. a river)

paraang - to take someone across

(c) slôoj - to be washed away by flowing water

salôoj- to discard into flowing water, to let something be washed away

(d) kliih - to go off (of a trigger or trap mechanism) kaliih - to set off a trigger or trap mechanism

(e) bsot - to go out (of light or fire) basot - to turn off, put out

(f) pdềè - to come untied padề $h$ - to untie

(g) kleer - to fall off (e.g., a fruit, a leech) kaleer - to pick off

(h) krangq - to be dried up, toasted karang $q$ - to toast, warm up

(i) blang - of the eyes, to become open (e.g. of a developing puppy)

balang - to open one's eyes 


\subsubsection{Verbalizing infix $-a-$}

The verbalizing infix $-a$ - is presumably related to the causative infix, just discussed. Further work is needed in order to clarify their relationship. This infix can be inserted into words with $\mathrm{C}_{0} \mathrm{C}$ onsets. The infix then occupies the $\mathrm{V}_{-1}$ slot and thereby creates a minor syllable. The erstwhile $C_{0}$ ends up in the new $C_{-1}$ slot. The function of the verbalizing infix $-a$ - is to derive a verb from a noun. Most of our examples (49a-c) are from a series of forms derived from body measure terms (with the derivational pattern 'body measuring term' $>$ 'action of measuring out using that body part'), but we also see verbalization from words for objects, as in (49d):

(49) (a) ckaang - a hand span

cakaang - to measure something by hand spans

(b) plaajh - an arm span palaajh - to measure something by arm spans

(c) cbuuc - a unit of whatever can be picked up pursehand (a 'pinch')

cabuuc - to pick up or measure out something purse-hand

(d) ckhaal - a diagonal cross-beam for support in base (e.g. in cariit 'back basket' or other woven artifact) cakhaal - to place a diagonal cross-beam in base (e.g., of cariit 'back basket')

Both - $a$ - infixes target only those words with $\mathrm{C}_{0} \mathrm{C}$ onsets. For words with other types of onset $\left(C V\left(C_{F}\right)\right.$ and $\left.\operatorname{CvCV}\left(C_{F}\right)\right)$, the kinds of semantic relations which these infixes denote will have to be coded by other means (i.e., lexically or syntactically, as is the pattern for languages like Lao and Vietnamese).

\subsection{Nominalizing infix $-m-$}

The nominalizing infix $-r n$ - is inserted into words with simple $C$ onsets. In the resultant syllable, the erstwhile $C$ becomes 
Phonology and sketch grammar of Kri, a Vietic language of Laas / CLAO 38(2009) 3-69

$\mathrm{C}_{-1}$, and the sequence $-r n$ - occupies the new $\mathrm{V}_{-1} \mathrm{C}$ slots. There is often an epenthetic vowel between $C_{-1}$ and $-r$ - The function of this infix is to derive a noun from a verb:

(50) (a) koorq - to scoop out strips of a vegetable (e.g. cassava) for food preparation

krnoorq - an instrument to scoop out strips of a vegetable (e.g. cassava) for food preparation

(b) paang - to signal one's ownership of a swidden prnaang - a sign placed in a swidden to signal ownership

(c) sat - to get one's foot stuck (e.g. in a snare) srnat - a foothold

(d) kooq-to live krnooq - a house

(e) keep - to pince krneep - tongs, pincers

(f) tajh - to tap, to strike trnajh - a flint stone

(g) cooh-to pierce crnooh - a hung thread, pierced through multiple objects

For verbs which already have a pre-C consonant, the $-r n$ - infix is reduced to $-r$-. The $-r$ - infix then occupies the $v_{-1}$ slot of the minor syllable, either by simply replacing the existing $v_{-1}$ if the source form had a minor syllable, as in (51a-c), or by being inserted between $C_{0}$ and $C$ of the source form, as in (51d), causing the erstwhile $C_{0}$ to end up in the $C_{-1}$ slot, and creating a new minor syllable:

(51) (a) kalêêng - to shoulder-carry with an ad hoc constructed pole krlêeng - an ad hoc constructed shoulder-carrying pole

(b) kaleeq - to point something out krleeq - sign used for pointing out beehives in trees

(c) kadôôlq - to rest the head on something krdôôlq-a pillow 
(d) tkap - to pince
trkap - a pince

The 'pillow case' (51c) in particular shows that the $-r$ - form is the derived one, since it has a very much more specific meaning (i.e., one can kadôolq 'rest one's head on' anything, while a krdôolq is something very specific for that purpose).

\subsection{Reduplication}

Reduplication is an inherent feature in a good many verbs in the lexicon (by 'inherent' we mean that there is no corresponding non-reduplicated form), where these all seem to involve repeated or prolonged action:

(52) (a) kôôn-kôon-to shoulder-pole something, with only one side loaded

(b) kuu-kuu - to wash out the mouth and spit out, e.g. after eating

(c) ceek-ceek - to pick the teeth (as ceek-ceek kasang, where kasang = 'teeth')

(d) dec-dec - to massage, repeatedly squeeze

In some cases, the root element may also be used on its own, denoting an event NOT repeated or prolonged.

(53) (a) tang - to chop up (meat)

(b) tanq-tanq - to chop up (meat) into tiny pieces, finer than tanq

When the input form has a minor syllable, there is partial reduplication. Only the major syllable is doubled:

(54) (a) careew 'green'

(b) careew-reew 'greenish' 
Phonology and sketch grammar of Kri, a Vietic language of Laas / CLAO 38(2009) 3-69

A number of lexical items show inherent reduplication, but where there is a less clear semantic relation to notions like repetition or sustained action:

(55) (a) boong-boong 'window'

(b) dii-diiq 'small'

(c) daa-daaq 'hurry'

(d) doo-dooq 'sort of'

(e) kôô-kôo 'tangled'

(f) rôô-rôô 'large logs left over from burning swidden'

(g) moo-moo 'follow, spy on'

\section{VERBAL MARKING}

\subsection{Negation}

There are three forms for negation:
(a) dêêh
(b) laa
(c) cùrù

These particles show distinct grammatical behavior. The form ciris is distinct from dêeh and laa in that it appears before the subject, not immediately before the verb:

(57) (a) cùrì hanq kooq NEG 3SG have 'S/he doesn't have (any).'

(b) *hanq ciǹr kooq 3SG NEG have (S/he doesn't have (any).)

(58) (a) hanq dêeh/laa kooq 3SG NEG have 'S/he doesn't have (any).' 
Enfield N.J. \& Diffloth G. / Cahiers de Linguistique - Asie Orientale 38(2009) 3-69

(b) *dêêhlaa hanq kooq

NEG 3SG have

(S/he doesn't have (any).)

The form dêêh can be distinguished from laa in that dêeh may appear on its own as a full utterance (e.g., as a simple 'no' answer to a polar question), while laa may not:

(59) Q cak qooc boo

2SG go PCL

'Are you going?'
A1. dêeh
A2. "laa
NEG
(NEG)
'No.'

We are unable to say at this stage of our research what conditions the selection of one or the other of these negation markers.

\subsection{Time, aspect and modality}

Below is listed a set of common modifiers of temporal, aspectual, and modal meaning in the verb:

(60) (a) V kadoroj 'often, all the time'

(b) kadang V 'just V-ed'

(b') kanaq V 'just V-ed' (also sometimes khanaq)

(c) V cdang 'only V'

(d) thồồ $\mathrm{V}$ 'progressive'

(e) khơờ V 'have ever'

(f) V qà-tààh-tààh 'just then'

(g) V baramq 'keep doing $V$ like that'

(h) V pii tining ' $V$ as before'

(i) samêêng $V$ 'almost $V$-ed'

(j) V lơờj ' $\mathrm{V}$ without ado'

(k) manêêt $\mathrm{V}$ 'probably $\mathrm{V}$ ' 
Phonology and sketch grammar of Kri, a Vietic language of Laas / CLAO 38(2009) 3-69

A very common general predicative marker is the particle $c i$, which appears before the verb, and often before the subject (if there is presubject material, suggesting a kind of 'second position' placement):

(61) teeq ci dêeh ruuq qa-nii

ISG PRED NEG know NOM-this

'I don't/wouldn't know (about) this.'

(62) qa-nii ci teeq dêeh ruuq

NOM-this PRED 1SG NEG know

'This, I don't/wouldn't know (about).'

\subsection{Adjectives}

Adjectives behave mostly like verbs, being generally accessible to the TAM marking just described, but can be distinguished as a sub-class by their inaccessibility to a special emphatic construction involving tôô tàn [be true]. Both verbs and adjectives may take tàn 'true, really' as an intensifier:

(63) vààl tàn

move.around true

'really moving around'

(64) qjồòn tàn

tall true

'really tall'

However, only verbs allow the more elaborate expression tôo tàn [be true]:
(65) vààl
tôô tàn
move.around be true
'really moving around' 


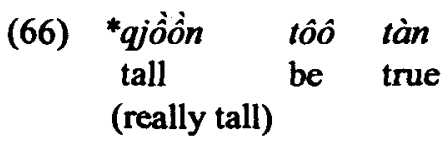

\section{SYNTAX}

\subsection{Constituent order}

Basic constituent order appears to be SVO, but this may not be the best way of analyzing the syntax, since many other kinds of structures routinely occur. There is free ellipsis of nominals when the identity of their referents is known (i.e., ellipsis is not syntactically determined or controlled). Postposition and fronting of noun phrases is common. There is no case-marking and no crossreferencing/agreement. This means that a surface string will always have a verb, but links between arguments and predicates may be hard to determine from surface form alone. Like other languages of mainland Southeast Asia, Kri requires a high level of dependence on context for resolution of grammatical relations.

\subsection{Subordination and serialization}

Kri features an explicit marker of subordination (kùù) between verbs in series, where most neighboring languages would lack this, having bare serial verb constructions instead. Here are some examples, in which kùù is associated mostly with a purposive relation:

(67) pdajh kùù vàt

flick SUB discard

'flicking (sth; e.g. a leech) off'

(68) qavààh

kùù qooc

push.aside.vegetation.to.make.way.through SUB go 'going (along) by pushing the vegetation aside to make way.' 
Phonology and sketch grammar of Kri, a Vietic language of Laos / CLAO 38(2009) 3-69

(69) qalêêng kùù cong

look suB see

'Look!'

(70) lêeq srdeel kùù sadeel

take a.plug SUB to.plug

'taking a plug to plug (something)'

(71) qeep kùù qalêêngq

be.quiet SUB look

'Be quiet and look.' (Mother to child, while looking at photographs.)

(72) qabeeh kìù tààjh

to.hook SUB pull

'hooking something so as to pull it (towards oneself).'

(73) lêê kùù paañq

take SUB sell

'taking something (e.g. wildlife) so as to sell it.'

(74) rơmq kùù hanq ciinq

keep.to.ripen SUB 3SG ripe

'putting aside green fruit so that it may ripen.'

(75) qeep kùù tềè

be.quiet SUB play

'Be quiet and play.' (Parent to child, asking child to play quietly.)

(76) lêêq kasề̀̀ q mee crnooh kùù cooh take cord make tie.cord SUB thread 'taking a cord to make a tie-cord, to thread it through (e.g. some fish).' 
Enfield N.J. \& Diffloth G. / Cahiers de Linguistique - Asie Orientale 38(2009) 3-69

Adverbial type expressions in which one verb is a modifier of another do not involve the subordinator kiù. Two orders are observed:
(a) lêêq klêê
take easy
(b) klêê lêêq
easy take
'easy to take'
'easy to take'
'go secretly'
(b) lôômq qooc
steal go
'secretly go'
(78) (a) qoơc lôomq
go steal

Note that the subordinator kùu marks the difference between the adverbial constructions in (78) and a purposive construction in which two predicates are linked in temporal-conditional succession:
(79) qoơc kùù lôômq
go SUB steal
'go in order to steal (something)'

Sometimes verb-verb sequences are not marked with the subordinator, as in the following example where soòk tzrôôh [seekmeet] may be a fixed idiomatic way of saying 'find':

(80) sòòk tzrôôh mleeng mee vềè boo dêeh seek meet person do work PCL NEG 'Have (you) found somebody to do the work?'

\subsection{Extra arguments}

The incorporation of added arguments - for example in adjuncts, or where three-place predicates license more than two arguments - show patterns of verb serialization which closely resemble those found in neighboring languages (cf. Lao, Enfield 2007). The Kri case differs in showing the use of true (i.e., nonderived) prepositions (here, $q u u$ 'at' and dêêwq 'from'): 
Phonology and sketch grammar of Kri, a Vietic language of Laas / CLAO 38(2009) 3-69

(81) book lêeq kààjh qù̀u tôôjq scoop take stone LOC bag/pocket 'scooping/picking out a stone in pocket.'

(82) pic sithiàn lêeq lôôh dêêwq nooj pull.out candle take exit from place 'pulling the candle out from (its) place.'

(83) lêê kààjh *(lêê) lôôh dêêwq vòòngq take stone take exit from pot 'taking a stone out from a pot." 18

(84) lêê lôôh kulò̀k dêêwq thang daak take exit head from bucket water 'taking the head out from a water bucket.'

(85) qôôm-qôôm phap tabồồn qù̀ tôôq carry.along.in.arms book place LOC table 'carrying along books (and) placing (them) on the table.'

\section{NOMINALS}

\subsection{Pronouns}

The inventory of Kri pronouns features a three-way distinction in number (singular, dual, plural), an inclusive/exclusive distinction in the first person non-singular forms, and a distinction in the singular forms between polite forms and bare forms. The bare forms are used unless polite forms are appropriate due to social distance (e.g., by age or kinship). There is a distinction in gender (male/female, only

\footnotetext{
${ }^{18}$ We know that lêêq 'take' is obligatory here simply because native speakers reject the sentence without it. However, we do not yet have any form of explanation for this, i.e., in terms of syntactic or semantic analysis. Here we merely report the fact of its unacceptability if omitted.
} 
distinguished in the third person singular polite form), though it could be argued that these are not pronouns, but nouns with meanings like 'respected lady' and 'respected gentleman'. Here are the forms:

\begin{tabular}{lllllll}
\hline & \multicolumn{1}{c}{ SG } & & DU & \multicolumn{1}{c}{ PL } \\
\hline BARE & POLITE & & & \\
& & & INCL & EXCL & INCL & EXCL \\
1 & teeq/pàànq & koon & saa & naaar & cawq & caa \\
2 & cak & mii & & maar & prii & \\
& & F & M & & & \\
3 & hanq & mooq & qốông & qaar & paa & \\
\hline
\end{tabular}

The pronouns can be used in inclusory constructions, of the type PRONOUN+[TITLE+NAME], for referring to groups of people identified by a specific sub-member who is mentioned by name, as follows:

$$
\begin{array}{lll}
\text { paa } & \text { vòok } & \text { nôn } \\
3 \mathrm{pl} & \text { grandpa } & \mathrm{N}
\end{array}
$$

'They of whom Grandpa Non is one'

$$
\begin{array}{lll}
\text { qaar } & \text { qaj } & \text { kham } \\
\text { 3du } & \text { non.resp.pref } & \mathrm{K}
\end{array}
$$

'Those two of which Kham is one'

(88) ñaar saaw knin

1 du.excl aunt $K$

'We two (excl) of which the other is Aunt Knin'

We do not yet understand the principles behind choosing who is the reference individual for the collective.

\subsection{Kin terms}

Kri society is fixated on kinship. Everyone in this small community is related to everyone else, and addresses each other 
accordingly. There are several broad categories of kin, determining the correct pattern of pronoun use (for first and second persons), and of third person reference (specifically, determining whether you can utter the person's name or not):

Table 15. Some kin categories, consequential for person reference. The distinction between 'higher' and 'lower' is grounded in sibling relations; those related to you via elder siblings of family members (e.g. your father's older brother) are 'higher', and mutatis mutandis for younger siblings.

\begin{tabular}{|c|c|c|c|}
\hline Kin category of addressee & $\begin{array}{l}\text { 1st person } \\
\text { pronoun }\end{array}$ & $\begin{array}{c}\text { 2nd } \\
\text { person pr }\end{array}$ & $\begin{array}{l}\text { Use of } \\
\text { name? }\end{array}$ \\
\hline $\begin{array}{l}\text { 1. clà-maangq 'kin of } \\
\text { same descent group' } \\
\text { (marriage not allowed) }\end{array}$ & $\begin{array}{l}\text { teeq } \\
\text { 1SG }\end{array}$ & $\begin{array}{l}c a k \\
2 \mathrm{SG}\end{array}$ & Yes \\
\hline $\begin{array}{l}\text { 2. mree "'higher' cià-maangq } \\
\text { of your spouse" }\end{array}$ & $\begin{array}{l}\text { ñaar } \\
\text { lDU.EX }\end{array}$ & $\begin{array}{l}\text { kin } \\
\text { term }\end{array}$ & No \\
\hline $\begin{array}{l}\text { 3. matààm/qujùù 's.o. married } \\
\text { to your lower cià-maangq } \\
\text { (e.g. younger sib. or child)' }\end{array}$ & $\begin{array}{l}\text { pàànq } \\
\text { 1SG }\end{array}$ & $\begin{array}{l}\text { maar } \\
2 \mathrm{DU}\end{array}$ & No \\
\hline $\begin{array}{l}\text { 4. kmoon "'lower' cià-maangq } \\
\text { of your spouse" }\end{array}$ & $\begin{array}{l}\text { koon } \\
\text { lSG }\end{array}$ & $\begin{array}{l}m i i \\
2 \mathrm{sG}\end{array}$ & Yes \\
\hline $\begin{array}{l}\text { 5. tààm/sawq 'someone married } \\
\text { to your elder sibling' }\end{array}$ & $\begin{array}{l}\text { teeq } \\
1 \text { sG }\end{array}$ & $\begin{array}{l}\text { kin } \\
\text { term }\end{array}$ & No \\
\hline $\begin{array}{l}\text { 6. sdoong 'mree of your own } \\
\text { child' (i.e. someone whose child } \\
\text { you are mree to) [these } \\
\text { pronouns used reciprocally] }\end{array}$ & $\begin{array}{l}\text { khoojq } \\
\text { 1sG }\end{array}$ & $\begin{array}{l}\text { nôoq } \\
2 \mathrm{SG}\end{array}$ & No \\
\hline
\end{tabular}

Note: For higher (i.e., older) cià-maangq, cak may not be used as 2sg pronoun.

If these rules prevent you from referring to a person by name, then you refer to them by their first child's name (teknonymy); i.e. if a man's first child is named kham then he may be referred to as pơơ $q$ 
qaj-kham 'father of Kham', or simply may be directly referred to with the child's name, as long as there is a title prefix such as an appropriate classificatory kin term, or a title such as qôong 'Mr.' or mooq 'Mrs'.

Here is a list of basic kin terms: ${ }^{19}$

(89)

\begin{tabular}{|c|c|c|}
\hline $\mathbf{F}$ & - & $p \grave{o} o ̛ q q$ \\
\hline $\mathbf{M}$ & - & mêêq \\
\hline eB & - & maangq \\
\hline$e Z$ & - & cì̀q \\
\hline yG & - & qeem \\
\hline Fyz & - & 900 \\
\hline FyB/HyB & - & pòòq \\
\hline $\mathrm{MyB} / \mathrm{WyB}$ & - & kùìqq \\
\hline MyZ & - & mureq \\
\hline $\mathrm{FeZ} / \mathrm{HeZ}$ & - & jaa \\
\hline FeB & - & puu \\
\hline $\mathrm{MeZ} / \mathrm{WeZ}$ & - & naaj \\
\hline $\mathrm{MeB} / \mathrm{WeB}$ & - & $t a a$ \\
\hline PP & - & vòo $k$ \\
\hline PPP & - & kôôq \\
\hline CC, etc. & - & cuuq \\
\hline $\mathrm{CCC}$ & & $c e c$ \\
\hline $\mathrm{CCCC}$ & & celavec \\
\hline $\mathrm{CCCCC}$ & & calavor \\
\hline
\end{tabular}

Some of the terms are 'skewed', extending in reference across generations, and across classes of kin. In the (90a-b) examples, one counts relatives of one's spouse as if one's spouse were one's parent (or, as if taking one's own child's perspective):

19 Abbreviations are: $B=$ brother, $C=$ child, $D=$ daughter, $e=$ elder, $F=$ father, $\mathrm{G}=$ sibling, $\mathrm{H}=$ husband, $\mathrm{M}=$ mother, $\mathrm{S}=$ son, $W=$ wife, $\mathrm{y}=$ younger, $\mathrm{Z}=$ sister. 
Phonology and sketch grammar of Kri, a Vietic language of Laos / CLAO 38(2009) 3-69

(90) (a) taa $=[\mathrm{MeB}, \mathrm{MFeBS}]_{\mathrm{cid-maangq}},[\mathrm{WeB}, \mathrm{WFeBS}]_{\text {mree }}$

(b) pòò $=[\mathrm{FyB}, \mathrm{FeBS}, \mathrm{FFyBS}]_{\mathrm{cià-maangq}},[\mathrm{HyB}, \mathrm{HeBS}]_{\mathrm{kmoon}}$

(c) matààm $=[\mathrm{DH}, \mathrm{yZH}, \mathrm{FyBDH}]$

6.3 Titles as prefixes for address

When addressing people, names can be prefixed by the relevant kin term (e.g., vò̀k-nôn 'grandpa Nôn'), or by another kind of title, such as the following:

(91) Titles

(a) qôông - 'sir, Mr.'

(b) mooq - 'ma'am, Mrs.'

(c) siàng - 'ex-novice' (novice $=$ junior monk)

(d) caan - 'ex-monk'

(e) liùng - 'uncle' $(<$ Lao)

(f) majồo - 'the late': a prefix for any dead person 'deceased'; also a term of insult for living people

\subsection{Demonstratives}

There are five distinctions in exophoric uses of demonstratives (i.e., references to physically present persons, places, or things):

(92) (a) nii general ('this')

(b) naaq external ('that', away, far)

(c) seeh distal ('yon', across, far)

(d) cồồ external down, downstream, below

(e) lêêh external up, upstream, above

At least (92a-c) have endophoric uses (i.e., discourse and anaphoric uses). In addition, there are two further demonstrative-type items, which only have endophoric functions:

(93) (a) tààh proximal

(b) nààq external (manner) 'thus' 
60

Enfield N.J. \& Diffloth G. / Cahiers de Linguistique - Asie Orientale 38(2009) 3-69

Demonstratives may occur as complements to nominal heads, placed after their heads:

(94) longq naaq

CLF dem.external

'that one'

Demonstratives may occur as adverbs:

(95) ciih quu tì̀k cồòh

descend loc below dem.down

'to go down to the ground'

(96) qooc qu trààh lêêh

go loc swidden dem.up

'to go up to the swidden'

(97) mơờj phàn seeh

ten thousand dem.yon

'ten thousand'

In the last example, seeh 'yonder' does not denote distance in space, but in 'possibility space'. Here, it expresses that ten thousand is an extreme, perhaps unexpected amount.

The term tààh occurs in a number of contexts which suggest that the word once had greater productivity than it does today: e.g., kỏoh-tààh 'today', qatààh-tảàh 'just this minute', and the common sentence-final particle tààh.

\subsection{Possession}

Possession may be explicitly marked by the classifier longq, but need not be: 
Phonology and sketch grammar of Kri, a Vietic language of Laas / CLAO 38(2009) 3-69

(98)

$\begin{array}{llll}\mathrm{N}_{\text {possessed }} & \text { (CLF) } & \mathrm{N}_{\text {possesser }} & \\ \text { cluu } & \text { (longq) } & \text { maangq } & \text { teeq } \\ \text { buffalo } & \text { (CLF) } & \text { eB } & \text { 1SG } \\ \text { 'my elder brother's buffalo' } & \end{array}$

\subsection{Modifiers}

Modifying elements such as adjectives and other verbs are placed after the head:

(99) N + MODIFIER

tukùùp qjồồn

hill high

'tall hill'

\subsection{Classifiers}

Constructions exist that look like the numeral classifier constructions, well described for mainland Southeast Asian languages (Bisang 1999). In Kri, as in many languages of the area, multiple orders are possible: both $\mathrm{NUM}+\mathrm{CLF}+\mathrm{N}$ (Sinitic/Vietnamese pattern, as in (100)) and $N+N U M+C L F(T a i$ pattern, as in (101)) are found:

(100) haar longq kadeeq

two CLF child

'two children'

(101) kadeeq har longq

child two CLF

'two children'

\section{ELABORATIVE LANGUAGE}

Like other languages in its family, and in the mainland Southeast Asian area, Kri has a range of expressive resources that 
may be termed 'elaborative', in that they elaborate upon existing forms, either through a form of morphophonemic derivation (echoformation), or through dedicated modifiers with special semantic content (expressives).

\subsection{Echo-formation}

There are lexically specified elaborative couplets, where a standard word has a lexically specified double (an 'echoformative'), which appears nowhere else but in the couplet: ${ }^{20}$
(a) rvajaj 'spirit/soul'
(b) rvaajg rloc 'spirit/soul and that sort of thing'
(b) thrirang 'stuff' thrìcang thràw
(c) pim pìn pò̀t 'stuff and that sort of thing'
(d) hin port 'grass' 'grass and that sort of thing' hunt hooj 'tobacco' 'tobacco and that sort of thing'

Less often, we find echo-formatives for verbs (with less predictable semantics):
(a) rooh 'dry'
rooh rap 'sort of dry, dry-ish'
(b) sangòòc 'quiet' sangò̀c sangeec 'dead quiet'

\footnotetext{
${ }^{20}$ We use the term 'echo' here in the standard sense (see the definition of "echowords" in the "Concise Oxford Dictionary of Linguistics" P.H. Matthews 1997:109), and thus do not define it explicitly here. These are not reduplicatives, but involve the addition of dedicated 'second elements' that serve to elaborate on more everyday words (e.g. 'chattels' in 'goods and chattels'). Here, they tend to share at least a small amount of phonological material, at least the first consonant.
} 
Phonology and sketch grammar of Kri, a Vietic language of Laas / CLAO 38(2009) 3-69

\subsection{Expressives}

The expressive word class (also referred to as ideophones) is found in most Eastern Mon-Khmer languages (Diffloth 1972), and in many Southeast Asian languages more generally (e.g., Lao, Vietnamese, Khmer, Semai, Sre, Bahnar, Pacoh, Khmu, Khasi, among others). These are phonologically elaborate, 'sound symbolic' in nature, and tend to convey narrowly defined perceptual experience. As the ( $\mathrm{g}-\mathrm{k}$ ) examples make explicit (with the expressives in boldface), they often follow, and have descriptive or modificatory scope over, a verb:

\begin{tabular}{|c|c|c|}
\hline (104) (a) & thòng thèèl & 'swinging big' \\
\hline (b) & teew-ngeewg & 'with head to side' \\
\hline (c) & tool-qoolq & 'head tilted back, looking up, chest out' \\
\hline (d) & vòò vò̀h & $\begin{array}{l}\text { 'shaking a torch up and down as one } \\
\text { makes one's way through the dark' }\end{array}$ \\
\hline (e) & vee veeh & $\begin{array}{l}\text { 'shaking a tiny torch side to side (or } \\
\text { up and down) as one makes one's } \\
\text { way through the dark' }\end{array}$ \\
\hline (f) & vôông vajh & $\begin{array}{l}\text { 'shaking a torch around in large } \\
\text { circles as one makes one's way } \\
\text { through the dark' }\end{array}$ \\
\hline (g) & cimg & 'raining' (v.) \\
\hline & cùng phiñ-phriñ & $\begin{array}{l}\text { 'raining very lightly, drizzling, } \\
\text { unceasingly' }\end{array}$ \\
\hline (h) & $\begin{array}{l}\text { sphiiq } \\
\text { sphiiq lang-ñang }\end{array}$ & $\begin{array}{l}\text { 'all different, mixed up' } \\
\text { 'all different, mixed up, very much so' }\end{array}$ \\
\hline (i) & ñông & 'bow down' \\
\hline (j) & $\begin{array}{l}\text { ñông khununuh } \\
\text { tìngq }\end{array}$ & $\begin{array}{l}\text { 'bow down with back bent over' } \\
\text { 'stand' }\end{array}$ \\
\hline & rimgq kdong-doongq & $\begin{array}{l}\text { 'stand leaning forward with bum } \\
\text { sticking out' }\end{array}$ \\
\hline
\end{tabular}




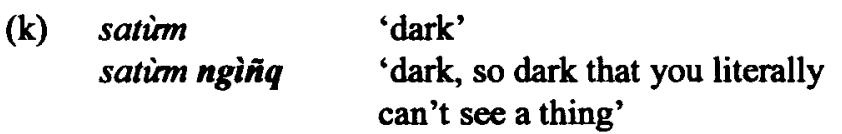

\section{FINAL REMARKS}

This brings to an end our introductory report on Kri, a previously undocumented Vietic language of Laos. We hope to have made a contribution not only to what is known about this language, but also to what is known about this branch of Austroasiatic. Current knowledge of Vietic is dominated by work on Vietnamese (and Muong to a lesser extent). As is the case for many language families, the best described members are often the least representative in typological terms. This is true for heavily Taiized Muong, and could hardly be more dramatic than in the case of Vietnamese, the outcome of 1000 years of Chinese influence, reinforced by a long period of national language status in addition (Nguyen 1980). Most other members of the Vietic branch, spoken by upland minorities in Laos and Vietnam (cf. Ferlus 1996), are closer in typological structure to Kri. Kri does, however, display a number of apparently exceptional features for a Vietic language, including full sets of terminance contrasts with de-voicing and postglottalization, a robust final $-r$, an initial palatal implosive $f$, unusual combinations in initial clusters (e.g., $f^{\circ} \mathrm{h}$ - and $\left.\mu^{2} v-\right)$, a lack of lexical tone, a set of derivational morphemes, an explicit marker of subordination in verb serialization, and a pre-sentential (rather than pre-verbal) negation marker. In order to judge the degree to which these and other features of Kri are exceptional, much more work needs to be done on $\mathrm{Kri}$ and related languages. Minority languages of the Vietic group remain seriously endangered, and are in urgent need of description. 
Phonology and sketch grammar of Kri, a Vietic language of Laas / CLAO 38(2009) 3-69

\section{REFERENCES}

ADB/UNEP (2004). Greater Mekong subregion atlas of the environment. Asian Development Bank (ADB), Manila, Phillipines, and United Nations Environment Programme (UNEP) Regional Resources Centre for Asia and the Pacific, Pathumthani, Thailand. Manila/Pathumthani : ADB/UNEP.

ALVES M. J. (1995). Tonal features and the development of Vietnamese tones. Working papers in Linguistics, University of Hawaii at Manoa, 27, pp. 1-13.

BISANG Walter (1999). Classifiers in East and Southeast Asian languages: Counting and beyond. In : Numeral types and changes worldwide, Edited by Jadranka GVOZDANOVIC, pp 113 - 185. Berlin: Mouton de Gruyter.

CHAMBERLAIN James R. (1997). Nature and culture in the Nakai Nam Theun conservation area. Unpublished manuscript, Vientiane 1997.

COSTELLO Nancy (1993). Katu folktales and society. Vientiane : Institute of Research on Lao Culture and Society.

DAVIS John J. (1968). Nyaheun phonemes. Overseas Missionary Fellowship. (Cited in Sidwell and Jacq 2003.)

DIFFLOTH Gérard (1972). Notes on expressive meaning. Chicago Linguistics Society, 8, pp. 440-447.

DIFFLOTH Gérard (1974). The KmMu' principle. In : Parmentier Festschrift, ed. E. Hamp. Chicago : University of Chicago Press.

DIFFLOTH Gérard (1984). The Dvaravati-Old Mon language and Nyah Kur. Bangkok : Chulalongkorn University Press. 
Enfield N.J. \& Difloth G. / Cahiers de Linguistique - Asie Orientale 38(2009) 3-69

ENFIELD N.J. (1999). Lao as a national language. In : Laos: culture and society. Edited by G. Evans, pp. 258-290. Chiang Mai : Silkworm Books.

ENFIELD N.J. (2005). Areal linguistics and Mainland Southeast Asia. Annual review of anthropology, 34, pp. 181-206.

ENFIELD N.J. (2007). A grammar of Lao. Berlin : Mouton de Gruyter.

ENFIELD N.J. (2009). Everyday ritual in the residential world. In : Ritual Communication, edited by Ellen BASSO and Gunter SENFT, Oxford : Berg Press.

FERLUS Michel (1996). Langues et peuples Viet-Muong. Mon-Khmer Studies, 26, pp. 7-28.

FERLUS Michel (1997). Problèmes de la formation du système vocalique du vietnamien. Cahiers de Linguistique Asie Orientale, 26(1), pp. 37-51

FERLUS Michel (1998). Les systèmes de tons dans les langues vietmuong. Diachronica, 15(1), pp. 1-27.

GAGE W. W. (1985). Vietnamese in Mon-Khmer perspective. In : Southeast Asian Linguistic Studies presented to Andre-G. Haudricourt. Edited by S. RATANAKUL, D. THOMAS and S. PREMSRIRAT. Pp. 493-524. Bangkok : Mahidol University.

GEDNEY W. J. (1993). The Saek language: glossary, texts, and translations. Michigan : Center for South and Southeast Asian Studies.

GREGERSON K. J. (1976). Tongue-root and register in Mon-Khmer. In : Austroasiatic Studies, Part l. Edited by P. N. JENNER, L. C. THOMPSON and S. STAROSTA. Pp. 323-369. Honolulu : University of Hawaii Press. 
Phonology and sketch grammar of Kri, a Vietic language of Laas / CLAO 38(2009) 3-69

HAUDRICOURT André-Georges (1946). Propagation phonétique ou évolution phonologique ? Assourdissement et sonorisation d'occlusives dans l'Asie du Sud-Est. BSLP, 43, pp. 82-92.

HAUDRICOURT André-Georges (1953). La place du vietnamien dans les langues austroasiatiques. BSLP, 49, pp. 122-8.

HAUDRICOURT André-Georges (1954). De l'origine des tons en viêtnamien. Journal Asiatique, 242, pp. 69-82.

HAUPERS R. (1979). Stieng-English dictionary. Dallas : SIL Publications.

HENDERSON E. (1952). The main features of Cambodian pronunciation. Bulletin of the School of Oriental and African Studies, 14, pp. 149-174.

HENDERSON E. (1965). The topography of certain phonetic and morphological characteristics of South East Asian languages. Lingua, 15, pp. 400-434.

HUFFMAN F. E. (1970). Modern spoken Cambodian. Ithaca, NY : Comell University, Southeast Asia Program.

KRUSPE N. (2004). A grammar of Semelai. Cambridge : Cambridge University Press.

MASPERO H. (1912). Phonétique historique de la langue annamite : les initiales. Bulletin de l'Ecole Française d'Extrême-Orient, 12, pp. 1-27.

MATISOFF J. A. (1973). Tonogenesis in Southeast Asia. In : Southern California occasional papers in Linguistics, No. I. Edited by L. M. HYMAN. Pp. 72-95. Los Angeles : University of Southern California.

NGUYEN D. H. (1980). Language in Vietnamese society. Carbondale, Illinois : Asia Books.

NORMAN Jerry (1988). Chinese. Cambridge : Cambridge University Press. 
Enfield N.J. \& Diffloth G. / Cahiers de Linguistique - Asie Orientale 38(2009) 3-69

QUY T.V. (2002). The Quy Hop archive: Vietnamese-Lao relations reflected in border-post documents dating from 1619 to 1880 . In : M. NGAOSRIVATHANA and $K$. BREAZEALE (Editors), Breaking new ground in Lao history: essays on the seventh to twentieth centuries. Silkworm Books, Chiang Mai. Pp. 239-260.

RAMSEY S. R. (1987). The languages of China. Princeton : Princeton University Press.

RIVIÈRE Captain (1902). Voyages au Laos et en Annam, pp. 215-294 of Mission Pavie Indo-chine 1879-1895 - Géographie et voyages, IV Voyages au Centre de l'Annam et du Laos et dans les régions sauvages de l'est de l'indo-chine, by Captain De Malglaive and Captain Rivière. Paris : Emst Leroux, 1902.

SAPIR E. (1921). Language: an introduction to the study of speech. Orlando/San Diego/New York/London : Harcourt Brace Jovanovich.

SCHLIESINGER Joachim (2003). Ethnic groups of Laos. Vol. 2. Profile of Austro-Asiatic-speaking peoples. Bangkok : White Lotus.

SHORTO H. (2006). A Mon-Khmer comparative dictionary. Canberra : Pacific Linguistics.

SIDWELL P. (2005). The Katuic languages: classification, reconstruction and comparative lexicon. Munich : Lincom Europa.

SIDWELL P. and P. JACQ (2003). A handbook of comparative Bahnaric: Volume 1, West Bahnaric. Canberra : Pacific Linguistics.

SUWILAI Premsrirat (1987). Khmu, a minority language of Thailand. Canberra : Pacific Linguistics.

SVANTESSON J.-O., D. TAYANIN, K. LINDELL, T. KINGSADA and S. SAYAVONG (1994). Kmhmu-Lao dictionary. Vientiane : Ministry of Public Health. 
Phonology and sketch grammar of Kri, a Vietic language of Laas / CLAO 38(2009) 3-69

THERAPHAN L-Thongkum (2001). Languages of the tribes in Xekong province, southern Laos: a foundation for research and development. Bangkok : The Thailand Research Fund.

THOMPSON L. C. (1987(1965)). A Vietnamese grammar, (Second edition.) edition. Honolulu/ Seattle : University of Hawaii Press/ University of Washington Press.

THURGOOD G. (2002). Vietnamese and tonogenesis: revising the model and the analysis. Diachronica, 19, pp. 333-363.

N. J. ENFIELD

Max Planck Institute

6500 Nijmegen

THE NETHERLANDS

Nick.Enfield@mpi.nl

\author{
Gérard DIFFLOTH \\ Ecole Française d'Extrême-Orient \\ Siem Reap \\ CAMBODGIA \\ gdiffloth@hotmail.com
}

